\title{
Change and Continuity in the Urban Semiosphere of Post-Soviet Kharkiv ${ }^{1}$
}

\author{
Svitlana Malykhina \\ Boston University
}

\begin{abstract}
The paper studies change and continuity in the urban semiosphere of Kharkiv in the post-Maidan period, focusing on themes such as the interplay of languages, street art, toponyms, and the significance of political, ideological, commercial, and artistic discourses in the urban space. The urban vernacular of Kharkiv is examined via the concept of the palimpsest that helps to expose the process of acceptance or rejection of the past, and to assess how things are remembered and forgotten through the tropes of the old narrative that were scrapped and replaced with new ones. The analysis of the linguistic landscape in this study focuses on a broader, more inclusive set of components that are part of public spaces, such as street graffiti metaphors and reactions to the text on graffiti. Thus, a multimodal approach is essential to provide deeper meanings and interpretations of public spaces. To examine the complex linguistic landscape, I bring together a representative collection of public signage that mirrors the dynamics of different historical, linguistic, and ideological factors that shape the contemporary Ukrainian identity, along with the too obvious and simultaneous presence within it of markers of the collective identity from the Soviet period. The juxtaposition of overlapping narratives provides a means to discuss the city's community-building efforts. My paper introduces a few familiar cases of how post-Soviet urban dwellers have shaped social spaces.
\end{abstract}

Keywords: Kharkiv, identity, urban, visual, palimpsest, vernacular.

${ }^{1}$ I thank Svitlana (Lana) Krys, Oleksiy Musiyezdov, and the anonymous reviewers who provided crucial feedback on this article. Earlier versions were presented at the BASEES Annual Conference at Fitzwilliam College in Cambridge, United Kingdom (April 2018), and at the Annual Convention of the ASEEES in Washington, DC (November 2016). I am particularly grateful to Nadieszda Kizenko for questions and feedback, and Mirna Šolić for extensive comments on a paper presented at the BASEES. I am grateful to Danielle Jones, Tomi Haxhi, and Ryan Green Tintera for feedback on earlier versions. My thanks also go to Hamlet Zyn'kovs'kyi, a Kharkivbased art designer, for a meaningful interview, and to Tat'iana Leonova for her very generous help in verifying the facts. I am also deeply grateful to my old friend Lidiia Starodubtseva, at the Centre of Media Communications and Visual Studies of the V. N. Karazin National University of Kharkiv, who alerted me to several specialized studies on this topic. The usual disclaimers apply. The opinions expressed in this article are those solely of the author. 


\title{
INTRODUCTION
}

\begin{abstract}
$\mathbf{A}$
s any other border town, Kharkiv embodies topographical paradoxes from imperial to contemporary periods: they are simultaneously marginal and central to both cultures, Russian and Ukrainian. I begin by laying out the details of this dichotomy because it is my goal to reveal it as unproductive and to show how the relationship between aspiring individuals' engagements with local, national, and global ideologies and dominant discourses of power complicate the notion of a coherent, territorially based nation.

I further collapse this binary perspective into a more nuanced examination of identities utilized by people in this region at multiple spatial scales to define their own notions of identity. While designing my ethnographic fieldwork, I set up goals to examine the semiotic landscape of the city and to provide key subtleties to its competing discourses - the Ukrainian national narrative, the Russian Imperial narrative, and a Soviet legacy. I finally decided to investigate how Kharkiv is responding to contemporary issues, and how changes and continuities are reflected in linguistic landscape.

Having laid the descriptive groundwork, in the remaining parts of this study I analyze the interrelatedness and prevalence of various narratives within a linguistic landscape. Through a semiotic analysis, I aim to show that individual artistic responses tend not only to refashion or restore the urban linguistic landscape but are likely to offer competing opinions and to voice artistic dissent. Moreover, within the play of this plurality we see that the Ukrainian tradition is currently undergoing an important paradigm shift.
\end{abstract}

\section{THEORETICAL REFERENCES THAT GUIDE THE ANALYSIS}

Early definitions of the term "linguistic landscape" vary greatly, and there is no ideal definition at the scholar's disposal. According to Landry and Bourhis, "The language of public road signs, advertising billboards, street signs, place names, commercial shop signs, and public signs on government buildings combines to form the linguistic landscape of a given territory, region or urban agglomeration" (25). It is clear that the concept of linguistic landscape here is used restrictively to describe the synchronic situation with a focus primarily on the language of public signs. However, even though it is possible to agree on the following general definitions of linguistic landscape, such as "environmental print," or "the decorum of the public life," these definitions restrict more than they facilitate understanding, despite the ease of comprehension they permit (Huebner; Ben-Rafael et al.). 
Since the Maidan protests in 2013-14, contesting forces, both local and global, can be observed in a relatively small location-in the city of Kharkiv. Although synchronic and diachronic binaries often present themselves as convenient organizational tools, it is not my intention here to work within their constraints. I propose, instead, a list of elements for a working definition of linguistic landscape and discuss the justification for the inclusion of elements from both synchronic and diachronic perspectives. Based on the perspective that language fulfills not only informative but also symbolic functions, linguistic landscape analysis can provide valuable insights into how languages exercise power-to co-operate or compete. According to du Plessis, "a change in regime can bring about a change in the linguistic landscape” (74). In an equally interesting turn, Gorter's work on linguistic landscape raises a related question: "How does the field of linguistic landscape mediate between incoherent and contested varieties of multiple forms of 'languages' as they are displayed in public spaces and the difficulty of assimilating past to present?" ("Methods and Techniques" 51; see also Gorter, "Further Possibilities"). Given the numerous traditions of the disciplines involved, there is little hope that there will ever be agreement on a common definition of linguistic landscape. Still, as Landry and Bourhis demonstrate, "the linguistic landscape may serve important informational and symbolic functions as a marker of relative power and status of the linguistic communities inhabiting the territory" (23).

I agree with Van Aschee and Teampău's claim that the urban landscape as a space of social interaction can be interpreted and analyzed as a palimpsest, taking into account cultural diversity and ethnic categories (12)..$^{2}$ By "palimpsest" I have in mind a complex combination of traceable and irremovable elements of a city's previous linguistic landscapes that can be found in the current one. Without taking into account multiple, changing, and often confused conceptions of identity mirrored in a nationwide (dis)orientation, the most controversial parts of the changing linguistic landscape could be swept aside. Analysis of the linguistic landscape focuses on a broader, more inclusive set of components, beyond written texts: graffiti, government signs, commercial signs, streets signs, advertisement, as well as visual data including monuments, street signs, storefronts, and mosaics, which are part of public spaces, and are documented in photos. This partial working definition may at least serve as a litmus test to examine the data outlined above across disciplinary boundaries. To define how urban space relates to identity, language, and power, I conducted an interdisciplinary research.

\footnotetext{
2 For more on this debate see Barnes and Duncan's Writing Worlds, wherein they claim that the analysis of physical landscape as palimpsest was generated by multiculturalism.
} 
Duncan's argument, which considers landscape as a text that links material form, shapes, culture, and space, serves as a key to the main premise of my study. I explore Kharkiv's urban vernacular as a palimpsest that registers changes in the city's urban and linguistic environments. The concept of the palimpsest is also used as a theoretical and tactical tool to compare synchronic and diachronic linguistic landscapes based on multiple observation points. Urban space is not just a place that permits, often inadvertently, the transformation of identity; on the contrary, specific aspects of urban space, such as built heritage and innovative design, actively contribute to the preservation of local identity (Gospodini 229). If analyzed from the theoretical perspective of symbolic power (Bourdieu), the linguistic landscape reveals how power relations between hegemonic and subordinate groups are shaped, and brings into focus different manifestations of language conflict (Bilaniuk). Some scholars, like Yurchak, examine the visibility of the new entrepreneurs in the names given to enterprises due to the privatization of public space, while others, like Bennett, analyze the symbolic comeback of the old Russian orthography. By looking at Kharkiv's urban vernacular as a palimpsest, I propose that it is through "re-writing" and "re-reading" the urban landscape, that the citizens empower the city.

\section{Methods And Techniques of DAta Collection And PRESEnTATion}

The selection of survey area remains problematic, as it is challenging to the point of being unfeasible to survey an entire city. Due to considerations of feasibility and practicality, I limited the focus of my study to the central part of Kharkiv, which serves as a representative sample for the whole city. The visual insignia of Soviet ideology and Ukrainian heritage in this neighbourhood is rich and full of authenticity. Data from informal conversations and a survey were used to support and extend the analysis of the data set, which included two hundred and sixty-five photographs of linguistic landscapes.

Since 2008, I have conducted ethnographic research in Kharkiv. The data presented here come from an analysis of my field note observations, transcribed recordings, a survey of 66 students at the V. N. Karazin National University of Kharkiv, focus group discussions, and informal conversations with 15 artists, ethnographers, journalists, and faculty at the V. N. Karazin National University of Kharkiv. Students majoring in Ukrainian journalism, Russian studies, publishing and editing studies, Ukrainian language and literature, and philosophy were randomly assigned to fill out the questionnaire. Some of those surveyed also participated in recorded informal conversations. Respondents came from different parts of Ukraine and therefore spoke different varieties of Ukrainian. My main task was to 
analyze self-reported language practices in order to examine the main dimensions of the Ukrainian national identity and personal choices of respondents in a community where Ukrainian is the only state language but communication in Russian is often expected. The interviews were analyzed through close reading, and I am responsible for the translation of quotes. My notes from everyday observations in the streets and of Ukrainian media were also coded thematically to uncover details that were not captured during recorded sessions.

Interviewees were encouraged to speak as freely as possible on the subject and were free to communicate in Ukrainian if they wished to do so. I employed a qualitative method for this project: short informal interviews and focus groups with Russian speakers and native Ukrainian speakers in Kharkiv. The data were collected to provide a language community backdrop, to describe the frequency and strength of linguistic contacts, and to consider speakers' personal attitudes to Ukrainian language varieties. In interviews with students in semi-structured focus groups or in informal conversations where social attitudes, ideologies, and values were discussed, my main task was to observe everyday language use.

\section{KHARKIVITES RECONSIDER THE “NATIONAL IDENTITY”}

In addition to a continuing focus on aspects of national distinctiveness, Kharkivites have increasingly engaged with a wider range of identities (personal identity, ethnic identity, urban dweller identity, city identity, spatial identity, language identity). The past five years have witnessed a reassessment and broadening of language use-Russian and Ukrainianand of conceptions of identity among ethnic Ukrainian, Jewish, and Russian populations in Kharkiv. Moreover, with the rise of globalization, a new player has appeared in the local markets: English. It is no surprise that the five years after the Maidan led to a full reevaluation of the bases of national identity. Kulyk's survey traces "recent changes in two main dimensions of Ukrainian national identity, namely its salience vis-à-vis other identities people have and its content, or the meaning people attach to their perceived belonging to the Ukrainian nation" ("National Identity" 589). In view of their strong attachment to locality and region, it is remarkable that Kharkivites tend to be particularly critical of the post-Euromaidan policies and remain ambivalent in their attitudes toward the Ukrainian state and nation. This conclusion is based on the 2017 survey's results, as discussed by Kulyk ("National Identity" 594). Before and during the most recent revolution in 2013 and 2014, opinions about the future in the eastern Ukrainian city of Kharkiv were very much divided. Such a reaction is hardly surprising in a 
city where locally important factors - wild capitalism, corruption, and weak rules of law and regulation-are pervasive. Kharkiv's leaders generally opposed the Maidan, but large numbers of the population (including the right-wing movement) have been against separatism.

However, the past five years have witnessed a reassessment and broadening of conceptions of identity among ethnic Ukrainian, Jewish, and Russian populations in Kharkiv. In addition to a continued focus on aspects of national distinctiveness, language, culture, territorial homeland, and-a new factor-nation-building, Kharkivites have increasingly engaged with a wider range of identities (local, regional, and European). Among these, the regional level has been the most productive; while integration into the European Union continues to receive strong approval, a European identity is still in the process of formation. Note that in everyday life Kharkivites slip easily from Russian into Ukrainian; official place-names and functions are sometimes given in Ukrainian in an otherwise Russian-language sentence. The consideration of such language use leads us to the concept of discourse communities.

There are multiple examples of what the American linguistic anthropologist Laada Bilaniuk has called "non-accommodating bilingualism," in which one person speaks Ukrainian and the other person speaks Russian (183). In the interviews with Kharkivites, "translanguaging" was practiced in four ways: to mediate understanding; to co-construct and construct meaning; to include an interlocutor (as both languages are simultaneously used to "talk things through"); to exclude the interlocutor (that is, speakers who do not understand Ukrainian) from the interaction, and to show knowledge (e.g., by trying out the words they know ) (185).

A blending of languages occurs in the speech of Russian native speakers who, while speaking quite proper Russian, sprinkle it with Ukrainian words either for stylistic purposes or because of an affinity for "crossing." Rampton defines "crossing" as "the use of language varieties associated with social or ethnic groups that the speaker doesn't normally 'belong' to" (489). The use of language on TV and radio shows can serve as a good illustration of this peculiar linguistic situation. After the outbreak of the 2014 conflict, the Ukrainian government did not introduce policies specifically to discriminate against the Russian language and Russian speakers in Ukrainian-controlled territories. However, it did place a ban on Russian TV channels to counter pro-Russian television programming.

As I have observed, the use of language in any given situation on sociopolitical talk shows is more a matter of contextual choice and of expressing one's identity than of the language one speaks. For example, a typical situation on the TV show called Bol'shaia politika s Ievgeniem Kiselevym (BigTime Politics) with Ievgenii Kiselev, a former Russian television journalist, who moved to Ukraine in 2008, is as follows: Volodymyr Hroisman, the 
former premier minister of the Ukrainian Parliament, who is Jewish, speaks Ukrainian. Mikhail Saakashvili, the former governor of Ukraine's Odesa region, who is Georgian, speaks Russian as a second language. Volodymyr Zelens'kyi, the Ukrainian president, whose primary language is Russian, speaks decent Ukrainian and can seamlessly switch to unaccented Russian. Kharkiv's Mayor Hennadii Kernes, who first opposed the revolution in Kyiv, then fled to Russia and returned recast as a Ukrainian patriot, predominantly speaks Russian. The Ukrainian guests speak Russian to the Russian-speaking participants, reflecting the etiquette in the larger society. When speaking to one another, Ukrainians choose various combinations. Usually Ukrainians speak Ukrainian to one another, but the local experts pose questions in Russian. The host may switch back and forth fluidly. It is common to have an entire conversation, including the questions from the audience, in two languages. Moreover, the show is not dubbed or subtitled, indicating that viewers in Ukraine are expected to understand casual conversations in both languages. It seems that Ukrainian bilingualism is the Ukrainian willingness to accommodate not only the Russian-speaking portion of the country, but it is also "a sort of automatic courtesy," "a matter of basic good manners," "when prominent people on television, or citizens in daily life, make efforts to speak the language that is easier for the other person" (Snyder). Another major factor that defines changes in the linguistic landscape is the distance (both political and metaphorical) between the citizens and those who control the local politics, as well as the public perception of the languages in question.

On the surface, what stands out most of all in the linguistic situation in Kharkiv is the individual freedom to use the language of one's choice. Reflecting on the everyday dynamics of bilingualism, one can assume that perhaps the reason for switching the languages (Russian to Ukrainian, Ukrainian to Russian) is to accommodate a wide and diverse audience. Therefore, this phenomenon should be referred to as "accommodating bilingualism," a term that feels more precise to me, since it puts the focus on the psychological and behavioural accommodation in bilingual and multilingual encounters. Many of my sources for this discussion are publications, including websites, social networks, and blogs. However, I have also drawn on my contacts at the V. N. Karazin National University of Kharkiv to interview former colleagues whose experience of multilingualism is casual at best. Taken together, they present a complex and shifting linguistic scene. As one of my former colleagues noted, "Speakers in border areas were exposed to both languages, Russian and Ukrainian, since their birth. Given the prevalence of Russian in eastern Ukraine, switching to Ukrainian hasn't been easy. Not only have I had to rewire my brain, I also must reconfigure my life, from friends to electronic devices" (Savchenko). 
The shift from Russian to Ukrainian involves a move from the linguistic practices that dominated the professional sphere in the 1990s toward attempts to identify with a different model of professionalism. In order to better understand the sociolinguistic situation in Kharkiv-the ultimate goal toward which this work is directed-we must first lay bare the oftenunquestioned binary assumptions ascribed to the use of languages in the current global context (continuity/rupture; authenticity/anonymity). ${ }^{3}$

\section{SOCIO-CULTURAL AND HistoricAl CONTEXT}

There is no doubt that Kharkiv 4 should not be included in the category of insignificant cities, but rather should be included in a category that may be termed "overlooked" cities. Kharkiv is a place where tradition and identity are always in flux. Although Kharkiv most often has been perceived as either Ukrainian or Russian, it would be more accurate to recognize the city as one that historically has received more autonomy than most other Ukrainian cities, and thus has developed a frontier society that contests cultural and political identities.

When we step back into the city's history, we see that the old clash of Ukrainian and Russian discourses in Kharkiv can be traced to the early modern era, when Vasyl' Karazin (1773-1842), a small local nobleman of Serbian origin and a descendant of a Ukrainian Cossack elite family on his mother's side, collected 400,000 roubles among the Kharkiv gentry to support Alexander I's desire to open a university in Kharkiv. The imperial government viewed Kharkiv as an inalienable part of the imperial state and Russian civilization. During this period, local teachers were required to speak Russian (the official language of the Russian Empire) to the students, and Russian teachers were generally preferred. Although the opening of the Ukrainian university in 1805 turned Kharkiv into a modern city, this event left the Sloboda elite, descending from the local Cossack nobility, disappointed. As Flynn pointed out, "Enlightened absolutism in Russia was not to be challenged by anything comparable to the 'aristocratic resurgence' of the West. Faced with a new university system that was organized on the

\footnotetext{
${ }^{3}$ My utmost thanks go to Andrew Lynch for drawing my attention to this issue and for his careful discussion of the authenticity and anonymity of bilingual speakers of Spanish. Much of what I say in this section goes over ground that Lynch and other scholars (e.g., Kathryn Woolard, Monica Heller) covered in their research on the commodification of language.

${ }^{4}$ For the sake of consistency, I have chosen to use the Ukrainian spellings (Kharkiv and Kharkivites) rather than the Russian spellings (Khar'kov and Kharkovites), even when they appear in documents originally written in Russian.
} 
enlightened absolutist's all-class principle, the gentry did not respond warmly" (219). The Russian Empire exerted the greatest geopolitical influence from 1667 to 1917. It is significant to note that in both Right-Bank and Left-Bank Ukraine during the nineteenth century, all official business and education took place in Russian, while publications in Ukrainian were outlawed in 1863 and again in 1876.

It is also worth noting that the range of opinions in Soviet historiography gives way to the views that after the Bolshevik revolution in 1917, Kharkiv became associated with a Ukrainian "national renaissance." However, there seem to be reasons to expect, as Liber aptly noted, that "unlike Russian writers, who were committed to Bolshevik state-building in the 1920s, Ukrainian writers were involved in nation-building" (123). The evidence that Bertelsen provides in her study on Ukrainian intelligentsia in Kharkiv demonstrates the case of "The House of Writers," the artists' commune building that witnessed the tragedy of those who in the early twentieth century were inspired by the Russian Revolution of 1917, but ceased being happy Stalinists by the early 1930s. Later, these intellectuals were marginalized as "nationalists" and arrested.

In the 1920s, the use of Russian by ethnic Ukrainians in Kharkiv was viewed as a legacy of Tsarist imperialism that should be liquidated as quickly as possible, but Russian speakers (of every ethnicity) were often disinclined to learn to operate in a new language, and passively resisted policies aimed at the linguistic transformation of the city. Therefore, intellectuals sought to provide national alternatives to what they saw as "Russian" organizations and established an exemplary set of cultural institutions promoting experimental culture, which engaged more specifically with the Ukrainian national culture (see Bertelsen).

In 1926, Les' Kurbas moved his Berezil' theatre to Kharkiv, adding the most prominent Ukrainian theatre to the modest collection of professional theatres operating in Kharkiv, then the new national capital. The troupe, made up primarily of Russophone workers drawn from the city's clubs, responded poorly to pressures to provide linguistic Ukrainization. They performed parts of their shows, sometimes even full sketches, in Ukrainian, but as one reviewer put it: "This is not Ukrainization, but a little bit of Ukrainian makeup on their face" (qtd. in Crane 203). ${ }^{5}$

Targets for Ukrainization routinely went unmet, leaving language one of the central tensions in the cultural life of Kharkiv for the duration of the 1920s. But the long process was set in motion. In January, 2018, the Iermylov Centre of the V. N. Karazin National University of Kharkiv hosted an

\footnotetext{
${ }^{5}$ On Kurbas, see Fowler; Kornienko; Makaryk; Makaryk and Tkacz. On other theatres in Kharkiv, see Paramonov and Titar'.
} 
exhibition titled "Kurbas in Kharkiv," a reflection on the experimentation and performances of Kurbas, a prominent figure of the world's avant-garde.

\section{YIDDISH LEGACY OF KHARKIV}

In the 1920s, among Kharkiv intelligentsia there were authors who made extensive use of Ukrainian, incorporating Polish and Yiddish elements in their Russian writings. The post-revolutionary, short-lived Ukrainian People's Republic (1917-21) was the first modern state to have a Ministry for Jewish Affairs, and Yiddish was made a state language. In that period, Kalman Zingman's ${ }^{6} 1918$ Yiddish-language novella, In Edenia, a City of the Future, was published in Kharkiv. ${ }^{7}$ A new world of cultural tolerance was a future utopian version of Kharkiv in eastern Ukraine. But pogroms continued unabated, and between 1918 and 1920, at least 31,000 Jews were killed in Ukraine - the real number may be as high as 100,000 (Cohn; Budnitskii, p 7, fn. 2). Zingman's futuristic vision of a city with complete Jewish emancipation, a place for peaceful existence of Ukraine's Jews, clashes horribly with the country's history. For more than 50 years, the details of the brutal tragedy in Drobyts'kyi Iar, in the period from December 15, 1941, through January 1942, where, according to Boissoneault, some fifteen thousand of Kharkiv's Jewish residents were killed in a mass shooting or forced into mass graves to die of exposure to infection, remained largely unknown. Only after the historical rupture, after a lapse into silence, did the commemorative events surface in Kharkiv's history. ${ }^{8}$

In 2017, the group of international curators that created an exhibit entitled Edeniia: V gorode budushchego (In Edenia, a City of the Future) to reconstruct the imaginary space of Zingman's 1918 Yiddish novella, raised the question of cultural dialogue. In contrast to the ironic and carnivalesque image of Kharkiv depicted in Oleksandr Irvanets"s most recent book, Kharkiv-1938, dotted with Russian classics and Western pop icons, Edenia is

\footnotetext{
${ }^{6}$ Kalman Zingman, a Lithuanian-born aspiring Yiddish prose writer, established a Yiddish publishing house in Kharkiv in 1917 where he published his own and other authors' literary works and two issues of the Yiddish-language Art Circle Journal.

${ }^{7}$ An art exhibition In Edenia, a City of the Future, inspired by Zingman's eponymous Yiddish-language utopian novella, was held in the Iermylov Centre that promotes, and in many ways re-enacts, the complex cultural identity of Kharkiv's rich multicultural landscape of the past.

8 In 1988, the newspaper Vechernii Khar'kov (Evening Kharkiv) published the first article about the mass graves in Drobyts'kyi Iar. The Memorial "Place of Bloody Terror, 1941-1942" was opened in 2002, and in 2005, a Mourning Hall was opened underneath the main structure of the complex.
} 
full of references and memorials that exalt the Jewish artists and writers Yitskhok Peretz, Roza Fayngold, Sholem Aleichem, and El Lissitzky.

The exhibit's curators, Larisa Babij (Ukraine/US) and Yevgeniy Fiks (US/Russia), engaged viewers in a rare and unique futuristic, multicultural, and high-tech imagined space, where diverse groups can live in harmony. In their exhibit, international curators discussed questions that had been missing in the public discussions of recent years. They drew parallels between different times and constructions of historical memory, and revived an unprecedented selection of Jewish cultural heritage and artifacts of the Yiddish culture, which still remains invisible in Kharkiv as well as in other urban regions of eastern Ukraine. ${ }^{9}$ From talking to local residents in Kharkiv, I get the impression that while Yiddish words and phrases pepper modern Ukrainian and Russian languages, there is neither a context nor an audience for discussing the legacy and changing nature of Yiddish language and culture in regard to the emergence of Ukrainian-Jewish identity in contemporary Ukrainian culture.

\section{SOVIET-ERA NoSTALGIA AND DE-CommUnIZATION}

Public art in Kharkiv exists in the context of an ongoing debate of which Soviet era artifacts should be preserved and why. This debate is revealing in two ways: first, destruction or preservation of urban architecture always concerns peoples' lives; second, the symbolic dimension of the urban landscape reveals specific traditions, lifestyles, and values. National identity in post-Maidan Ukraine poses an especially interesting set of questions because of the closely intertwined histories of Ukraine and the USSR.

By looking at the "remnants of socialism," one can learn how Kharkivites perceived traces of the urban landscape through time, before 1989. Little effort, however, has been made to preserve the heritage of Mykhailo Boichuk, ${ }^{10}$ whose frescos, like the one in the Kharkiv Chervonozavods'kyi Ukrainian Drama Theatre, were destroyed during the socialist years. The themes of his art had outgrown propaganda and combined techniques and forms of traditional Byzantine and Ukrainian icons, the Italian Renaissance of the Quattrocento period, and Ukrainian folk art with formalist theories.

\footnotetext{
${ }^{9}$ In the 1800s, Ukraine was increasingly incorporated into the Russian social and cultural world. When other forms of organized Ukrainian nationalist activity were impossible, the Ukrainophile cultural movement attempted to combat the total Russification of the region by publishing a Russian-language journal of Ukrainian historical studies, entitled Kievskaia starina (Kyivan Antiquity). For a brief discussion of Kievskaia starina, see Szporluk.

${ }^{10}$ For further discussion, see Shkandrij.
} 
Meanwhile, although the mosaics of Lenin, Marx, and Engels, and the hammer and sickle have been removed, symbolic Soviet icons are still to be found. To date, I have been able to identify quite a few rapidly disappearing mosaics, bas-reliefs, sculptures, and monuments.

As I hinted at earlier, the seemingly paradoxical ascription to the linguistic landscape of both continuity and fragmentation proves, in fact, to be quite strategic. It seems that the original symbolism of monuments that were removed, closed, or demolished was eradicated. The "contested" nature of such sites meant that each decision to rename, remove, or redefine one was made and fought over individually, with no single political group able to completely enforce its (re)interpretation of Lenin or Marshal Georgii Zhukov. In effect, the city authorities may have put their ideology to sleep for a long winter, so that later it could be resurrected "after the break" and the mission resumed. Here, I discuss the case of the statue of Marshal Zhukov (and other statues-personifications of the Soviet past, and a constant reminder of the Soviet Union's quasi-religious veneration of its secular leadership) that reflected the ambiguous symbolic Soviet legacy. On June 2, 2019, far-right nationalists destroyed a monument to Marshal Zhukov, and a scuffle with law enforcement officers occurred. It should be noted that the Russian news propaganda site Gazeta.ru falsely reported that "the monument was destroyed by the Nazis," attempting to draw a plausible parallel to the "Estonian" Bronze Soldier affair of April 2007 (Apuleev). Incongruously, back then the mayor of Kharkiv, Mykhailo Dobkin, of the Party of Regions, suggested in an open letter to the mayor of Tallinn, that Tallinn consider a transfer of the Bronze Soldier and the reburial of the remains of Soviet soldiers in Kharkiv; the Dobkin plan was refused.

No mainstream contemporary political force saw an advantage in incorporating the blatant Soviet symbolism of these sites into new nationbuilding repertoires. These sites were either simply ignored or became subject to massive redefinition and reconstruction. Many busts of Lenin, or empty pedestals with the inscription "LENIN," or stone blocks with inscripted names of socialist icons are hidden and locked away in remote places. As such, they can be seen as metaphors that function as an imaginative tool for understanding and ordering the world (Lakoff and Johnson). In this sense, empty granite pedestals affect people's imaginations and play a central role in constructing a new social and political reality.

In contrast to the hidden remnants of the monuments in Kharkiv, an example of the symbolic usage of the Soviet past is seen in the display of socialist mosaics. In addition, the aesthetics of a bygone artistic era, as well as an interest in preserving memories of the past, are specifically visible in mosaics on the façades of factories, research institutions, and Palaces of Culture built in the 1960s. Since that time, many mosaics have fallen into disrepair and neglect. Nevertheless, to date, in Shevchenko Park, the Ukraine 
Cinema and Concert Hall boasts an example of a mosaic portraying a young musician in need of inspiration, who is gazing wistfully at endless golden fields in the middle of which one can see a tractor and a group of industrious peasants (Figure 1). This sort of image is regularly featured in national literature, historic films, and even in advertising as a trope of the "farmer" mentality. The shiny yellow and blue tiles depicting a bright sun in a blue sky are set in circles against a nuanced grey and smoky background reminiscent of the utopian images of the village as an important symbol of the Ukrainian nation (Wilson).

\section{Figure 1. The Ukraine Cinema and Concert Hall in Kharkiv. Photo courtesy of the photographer, Dariia Iurovs'ka.}

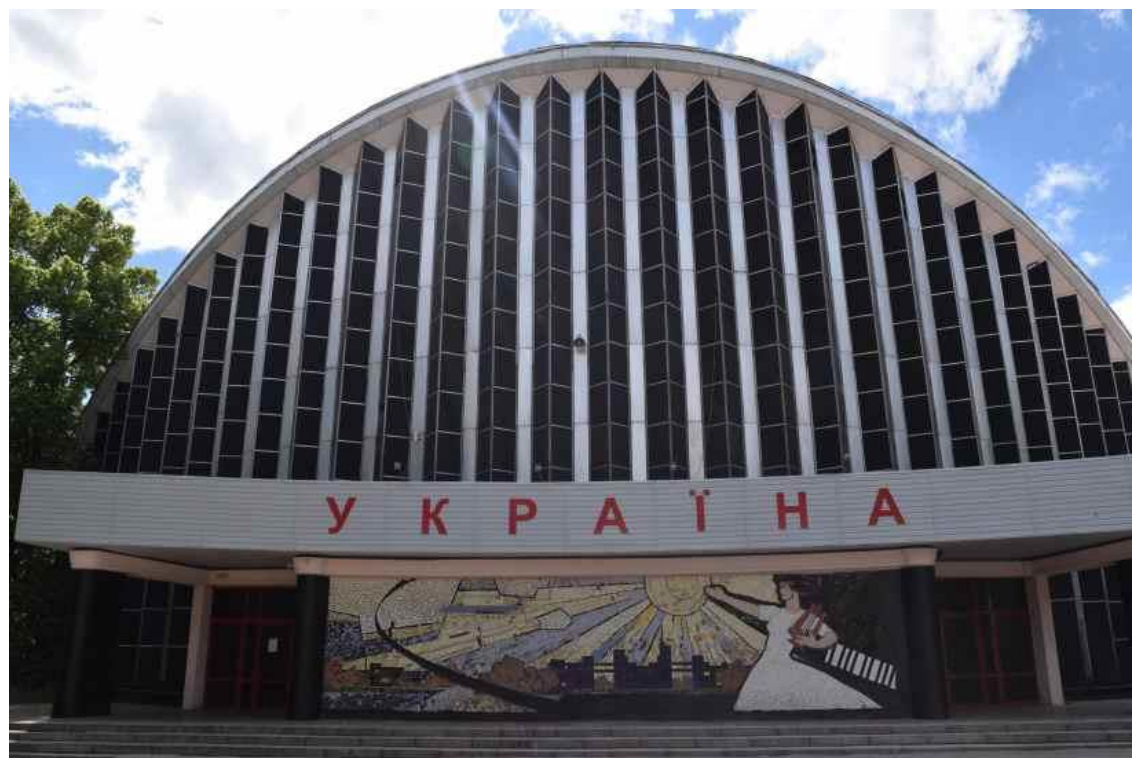

Another case of the "usable past" is the complex composition that illustrated a myth rather than a historical event. The giant mosaic by Sergei Svetlorusov ${ }^{11}$ (Figure 2) that was mounted over the door to the B. Verkin Institute for Low Temperature Physics and Engineering of the National Academy of Sciences of Ukraine (NASU) stylized the Cruiser Aurora beaming the light, which heralded the beginning of a new era, the era of the Great Socialist Revolution. Next, a giant figure of Lenin was depicted, and a group

\footnotetext{
${ }^{11}$ Svetlorusov's ceramic mosaic dedicated to V. I. Lenin on the façade of the Institute of Low Temperature Physics and Technology at the National Academy of Sciences of Ukraine (NASU), Kharkiv, 1968, is no longer in situ.
} 
of marching soldiers who are gazing at the symbol of a peaceful atom. Keenly aware of technology's importance to the development of a strong USSR, the author of this mosaic used a machine and modern equipment motif as a symbol of a new era.

\section{Figure 2. B. Verkin Institute for Low Temperature Physics and Engineering of the National Academy of Sciences of Ukraine (NASU). Photograph by Eugene Nikiforov.12}

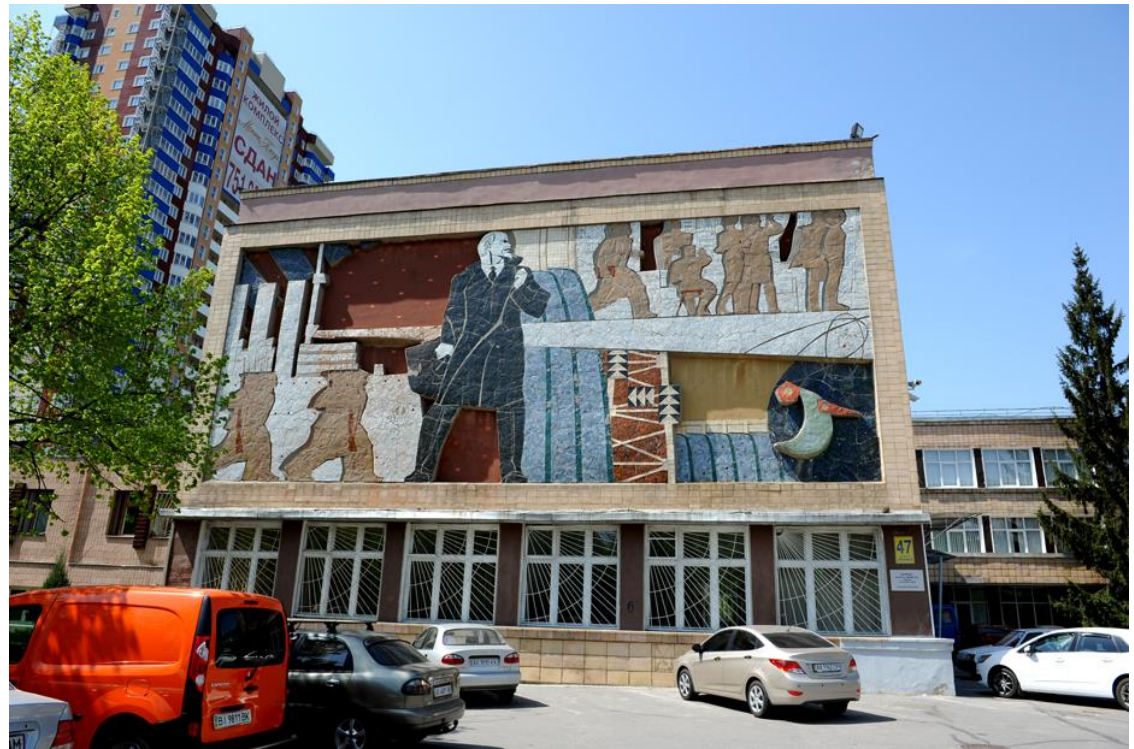

In fact, there is little appearance of the natural world in the next mosaic or sgraffito (see Figures 3 and 4), yet another reflection of the supremacy of the machine-the manmade-like benign fantasy of the future. In the mosaic in Figure 5, the close-up of the skyscraper is abstracted as a background geometric grid that immediately connotes modernity.

12 Source: https://birdinflight.com/inspiration/project/pixel-art-mosaics-of-thesoviet-ukraine-in-eugene-nikiforov-s-project.html. Accessed 12 Nov. 2019. 
Figure 3. Photo courtesy of the photographer, Dariia Iurovs'ka.

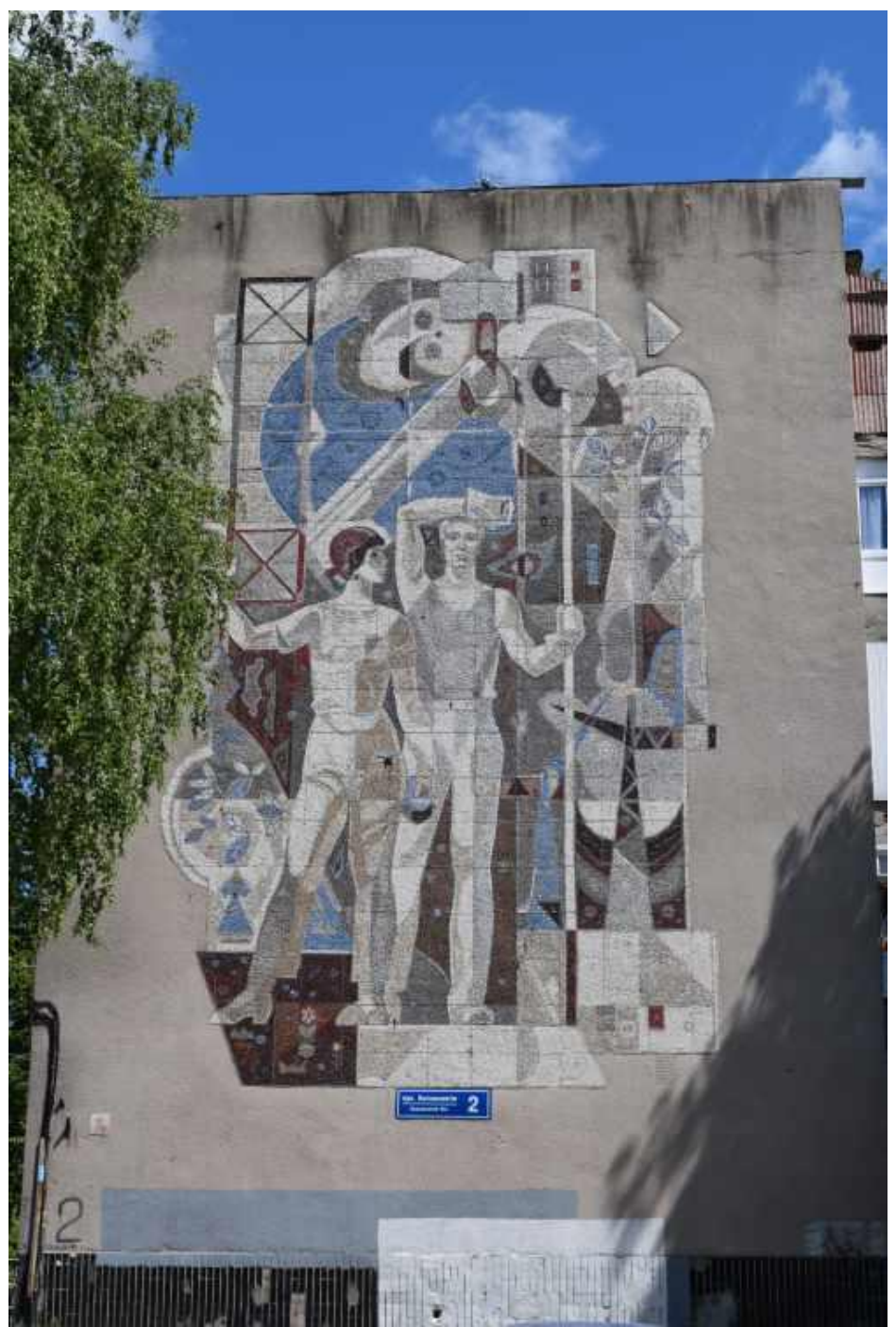


Figure 4. Photo courtesy of the photographer, Dariia Iurovs'ka.

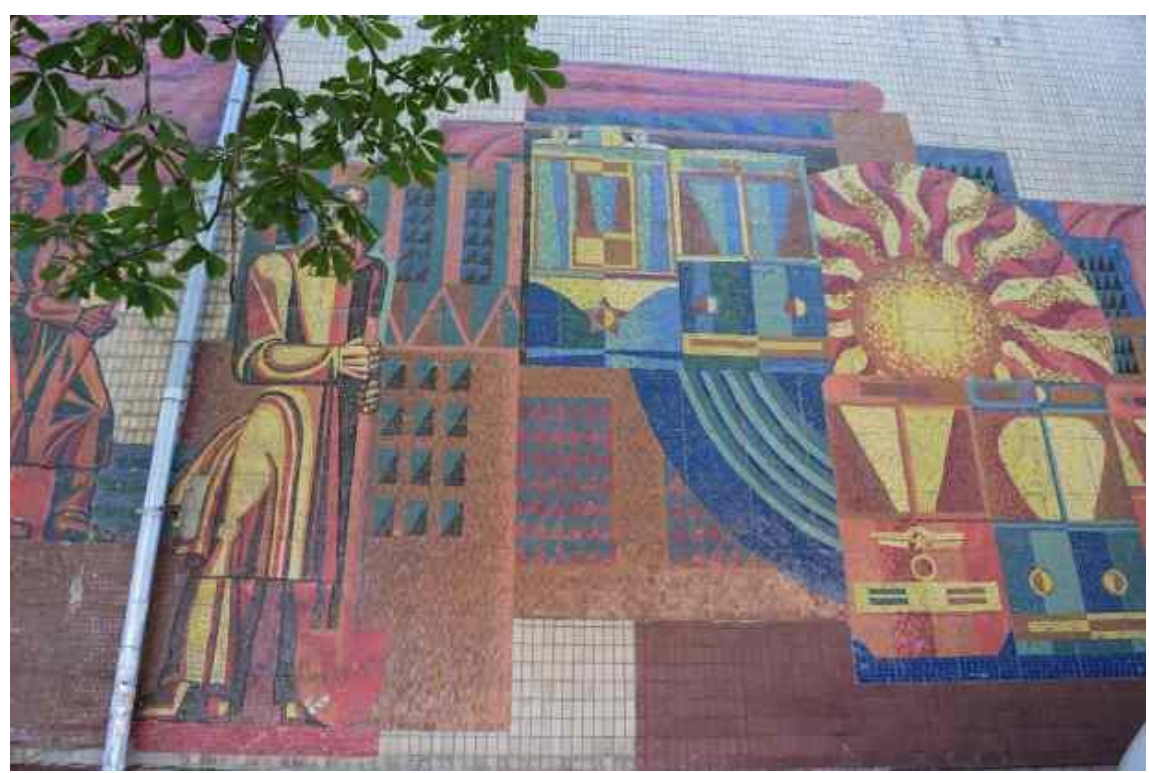

(C) 2020 East/West: Journal of Ukrainian Studies (ewjus.com) ISSN 2292-7956 Volume VII, No. 1 (2020) 
Figure 5. Photo courtesy of the photographer, Dariia Iurovs'ka.

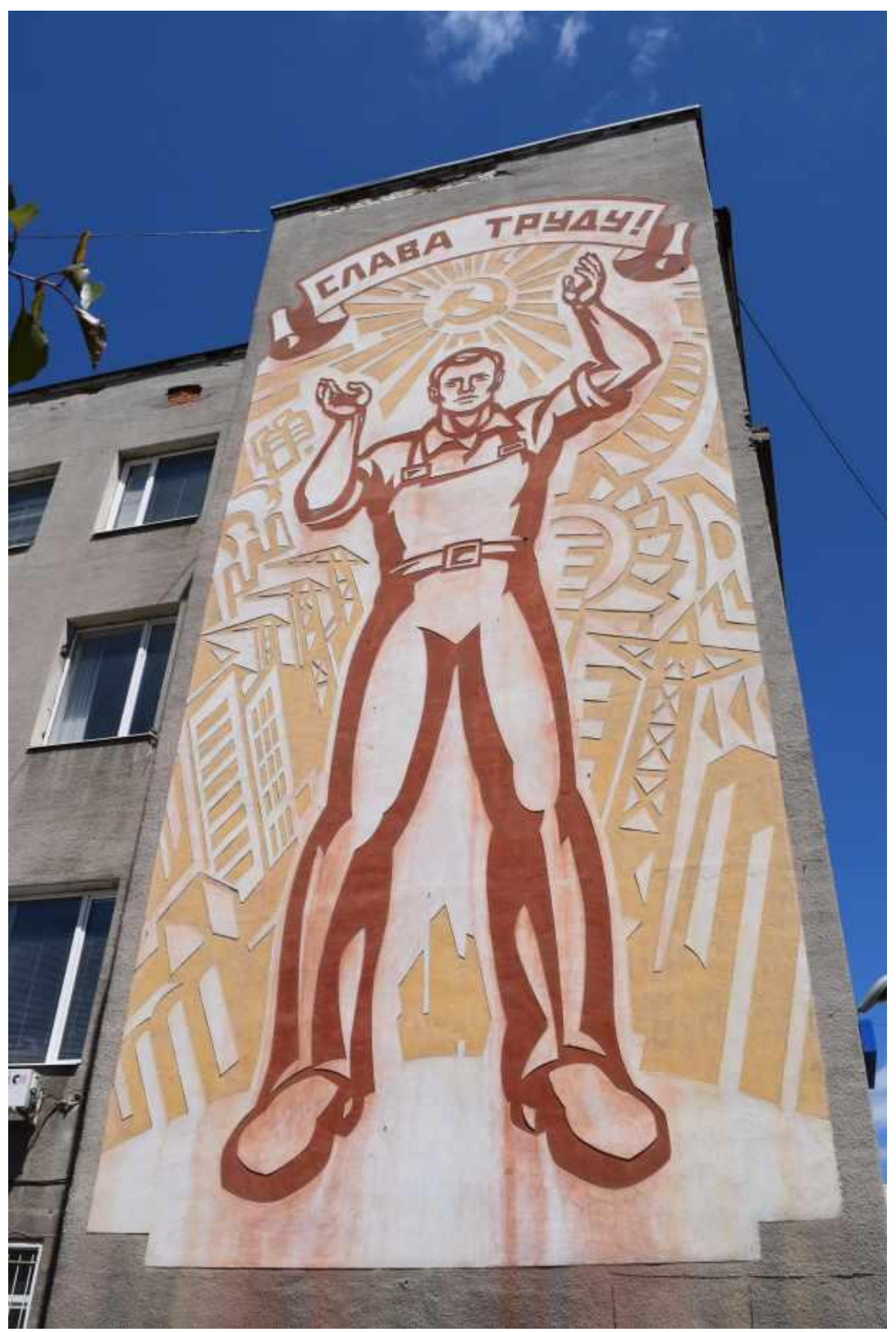

(C) 2020 East/West: Journal of Ukrainian Studies (ewjus.com) ISSN 2292-7956 Volume VII, No. 1 (2020) 
My next example is a mosaic that includes four children and appears on the frontispiece of the Kharkiv Academic Puppet Theatre. We see four puppets holding hands (Figure 6). The dominating figure in the "budenovka" (the pointed helmet worn by Red Army soldiers) is strongly evocative of a fictional character in Arkadii Gaidar's children's story, "Skazka o voennoi taine, Mal'chishe-Kibal'chishe i ego tverdom slove" ("The Tale of the Military Secret, Mal'chish-Kibal'chish and His Firm Word"). The fictional character's superpowers were bravery and an ability to keep a "military secret," and his motto was "All we need is to make it through the night and get through the day" (Gajdar). ${ }^{13}$

Figure 6. Photo courtesy of the photographer, Dariia Iurovs'ka.

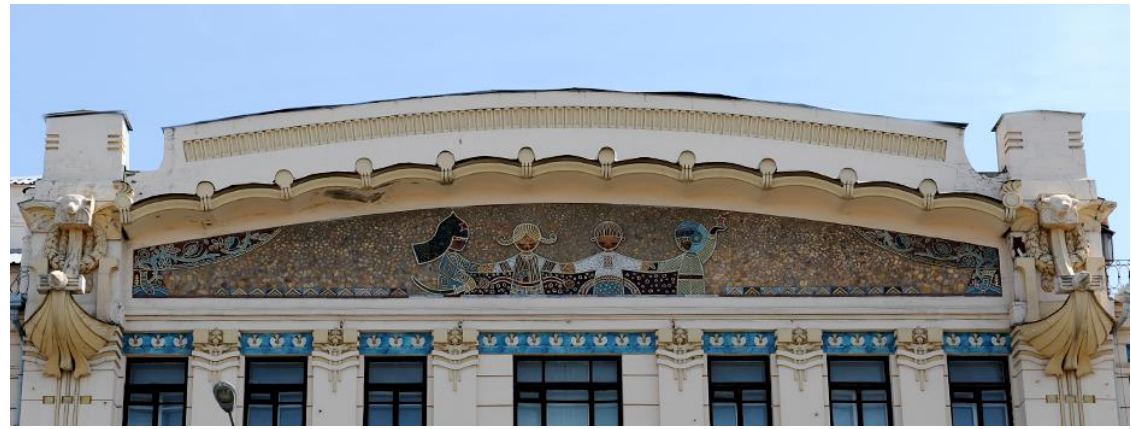

There are other examples of mosaics and sgraffito that propagate images of the new Soviet man, both as a distinct individual and as a "little cog," or that depict athletic men and women, presumably Iurii Gagarin and Valentina Tereshkova, soaring in the sky like airplanes (Figure 7). Abstract elements, or the type twist and spin around them, suggesting invisible forces at play. Figures are rarely at rest; they fall or spiral through space, sometimes in and out of the picture plane. Ubiquitous symbols of the socialist past, such as the hammer and sickle (Figure 5) or the USSR quality mark pentagram (Figure 8) are very popular.

13 Unless otherwise indicated, all translations are my own. 
Figure 7. Photo courtesy of the photographer, Dariia Iurovs'ka.

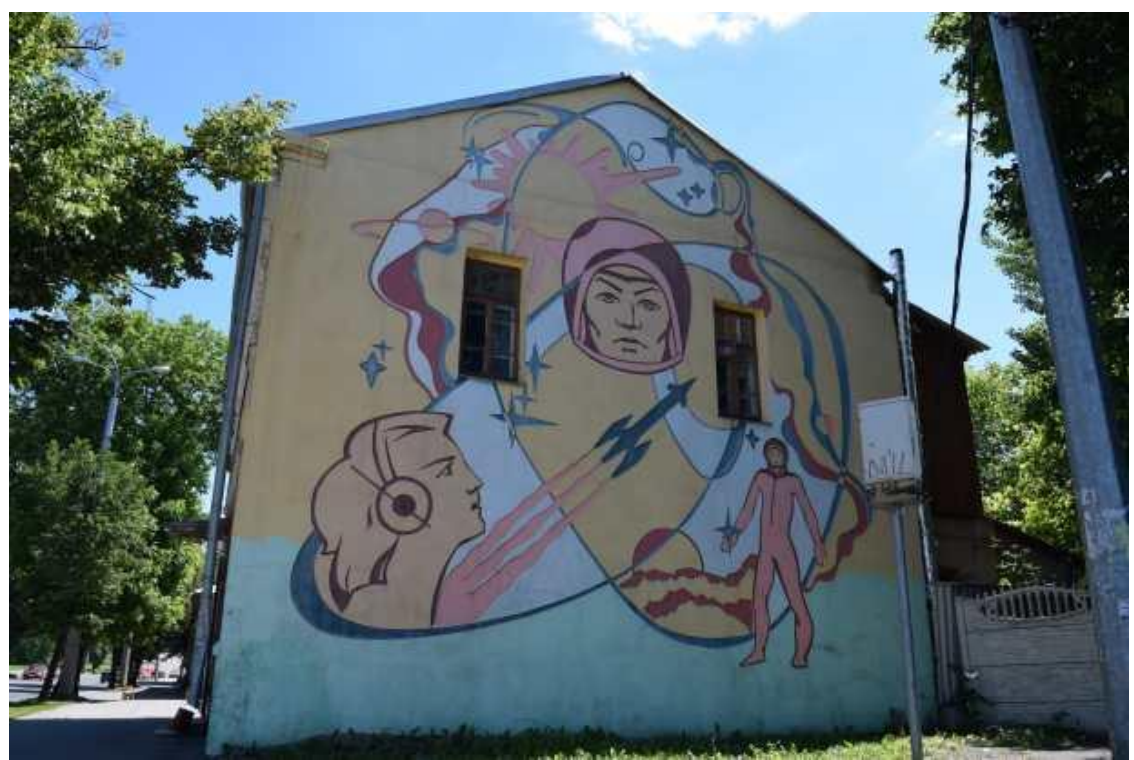

Figure 8. Photo courtesy of the photographer, Dariia Iurovs'ka.

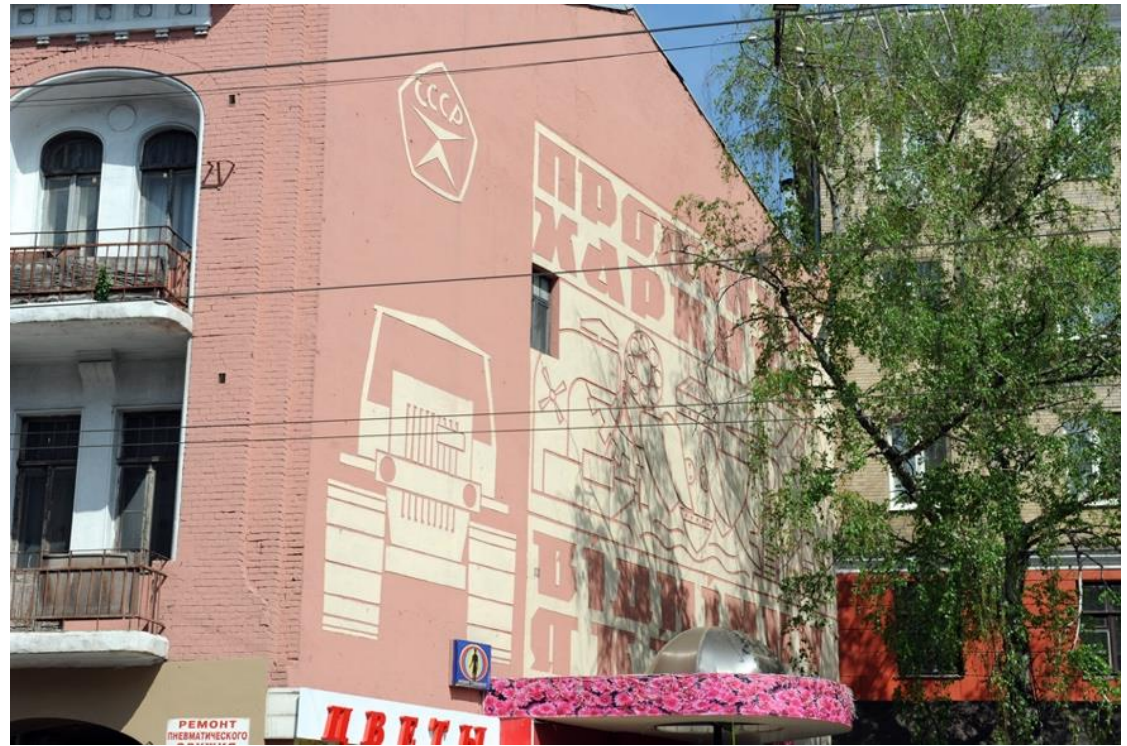

(C) 2020 East/West: Journal of Ukrainian Studies (ewjus.com) ISSN 2292-7956

Volume VII, No. 1 (2020) 
Visual imagery in public spaces reinforces the metaphorical merger of humans and technology, depicting people as if they were a technical achievement of the new Soviet epoch. The imagery was powerful, and it affected Soviet viewers on a raw emotional level. The socialist street visuals phenomenon created a multiplicity of meanings in both public and private spheres in the Soviet Union. This visual heritage is not only stored and perceived passively, it also actively participates in contemporary visual cultural turnover. This motif highlights how Communism remains so politically prominent in Kharkiv today. Furthermore, it brings to the fore one of the main themes of this work: generational change in perception and the enduring power of the absent presence of the past. Thus, Communism was not simply invoked through leftovers, it was invoked as a way of assessing the present, while being open to all kinds of parodies, like the ones demonstrated in graffiti.

\section{BilinguAl AND TRILINGUAL STREET SignS}

While the Russian language has lost its traditionally strong position in Kharkiv's linguistic landscape, it is still used in some subsets of street signs. In some contexts, English has taken a leading role in replacing the language in these signs. It is also observed that names such as "hastronom" ("big food store") and "univermah" ("department store"), that were widely used during the Soviet period for some commercial establishments, have completely disappeared. Instead, names such as food market, boutique, and mall have emerged. Such letterform experiments are not confined to the Cyrillic alphabet. In "Le Silpo,"14 for example, Roman letters in various styles are combined in addition to adding the article "le" to evoke a French context. One of the interesting trends here is the creativity of the shop owners who came up with a unique title by combining elements of French and Ukrainian using a language blending technique. New word coinage is one of the latest trends in street sign design, it is seen in language mixing, the blending of Ukrainian and English or French elements, and in transliteration, where the Ukrainian words are written in Latin-for example, the name of the café "The Varenyk," where "Varenyk" is the Latin name of a dish in Ukrainian cuisine.

On the other hand, among the monolingual signs, there are also Russian signs in the old imperial orthography, such as "Apteka" (Pharmacy) or "Bulochnaia" (Bakery). As a social practice, the choice of the old orthography and scripts in public signage may carry symbolic functions for the intended

\footnotetext{
14 "Sil'po" is a word for a village grocery store. Silpo is a Ukrainian retail corporation that operates a chain of grocery stores.
} 
audiences and reflect certain ideologies and discrepancies in the language choices of the business owners. Also, this localization of foreign patterns is pointing at conflicting temporalities, or more precisely at the sedimentation of the different time periods' remnants, emphasizing that the process of renaming is a "work in progress."

This situation also reveals the psychological and pragmatic considerations of those who construct the urban landscape. According to Aneta Pavlenko, "it is possible that these signs diverge from the official language norms but fit within agreed-upon local norms" (267). It is possible, however, that in its current development, contested styles are an inevitable feature of Kharkiv's palimpsest. The display of political independence, along with the dominance of postmodernist kitsch, may demonstrate a resurgence of the national idea, and at the same time a struggle over identity in progress. This is not atypical of the entire post-Soviet space.

\section{STREET NAME CHANGES}

Another element of the city's linguistic landscape is the renaming of its streets. ${ }^{15}$ After the Maidan protests of 2013-14, an ongoing process of deCommunization has been launched in Kharkiv and is still of great importance. In the four years since the Verkhovna Rada passed a package of four de-Communization laws in April 2015, 163 street names have been changed. Most of the changes were made without protest. Local officials have been especially diligent in changing the names of streets and squares named after Communists. There are no longer streets named after Karl Marx and Friedrich Engels. In their place, the new authorities are imposing old names like Blahovishchens'ka and Rizdviana streets. Gone is the name of the French novelist, a member of the French Communist Party and the author of Stalin's biography, Henri Barbusse. This street was renamed after Jura Soyfer, an influential Austrian political journalist and cabaret writer known for his uncompromising opposition to Nazism. He was born in Kharkiv and became a refugee at the age of eight when his family fled the Russian Revolution and finally settled in Vienna where he became fluent in German. He wrote his most famous legacy while in Auschwitz, and it became the lyrics of the

\footnotetext{
15 To give a little more context, it should be noted that when Ukraine asserted its independence from Russia in 1991, this was not carried across the Slobids'ka Ukraine in the naming of streets, government offices, stores, and services. Russian signs were replaced with Ukrainian signs only recently, and in some cases it was English (not Ukrainian) that was placed in the privileged position over the formerly dominant Russian.
} 
"Dachau Song" with a reference to the infamous cast-iron phrase "work will set you free." 16

My next example demonstrates that the contemporary practice of renaming is never produced exclusively by institutional discourse but is constantly reinterpreted by different social groups. I draw on the case study of the above-mentioned recent demolishing of the bust of Marshal Zhukov by a group of far-right activists and nationalists who claimed that it violated Ukraine's law banning Communist symbols, ${ }^{17}$ and the simultaneous City Council decision to revert to the Marshal Zhukov toponym. On June 19, an online street naming petition called for a renaming of Petro Hryhorenko ${ }^{18}$ Avenue, and the name "Marshal Georgii Zhukov Avenue" was approved. Mayor Gennadii Kernes supported this petition, observing that "it's impossible to overestimate his merits in defeating fascism" (Ivanova).

Drawing on the work of Pierre Bourdieu, recent studies have suggested that toponyms have become a new form of "symbolic capital," or a means of creating social distinction and status for both elite and marginalized groups. The above example also demonstrates that toponyms are not fixed and immutable. The name Marshal Zhukov is associated with victory over Nazism in World War II; it is simultaneously strongly connected with the rehabilitation of the Soviet past. This wide scale expatriation of the great military commander's name sends a resounding message to the rest of the world, while the symbolic capital of his name revives the memory of a larger, more powerful Soviet Union. Arguably, over time, the transposition of avenue name from a conscious use (in terms of understood links to autobiographical memory) to an unthinking use, where the name no longer conveys memories to the user, emerges through collective and cumulative repetition. As such, a battle for control over the renaming of an avenue by city officials has national resonance and relevance, and contributes to a larger mythology of urban landscape-one that is much more influential than the sum of its parts.

\footnotetext{
16 "Arbeit macht frei" - the slogan at the entrances to a number of Nazi concentration camps and an epitome of the cruel Nazi irony.

17 Field Marshal Georgii Zhukov is a contemporary Russian national hero, seen as the man who defeated Hitler and saved Russia and Europe from the Nazis. In Russia, the obsession with Zhukov was rhetorically glorified and co-opted for political purposes to boost Russian nationalism harking back to the glories of the Soviet past.

18 Petro Hryhorenko, Major General of the Red Army, military science professor, and later an oppositionist and a human rights activist, in particular for the rights of Crimean Tatars to return to their homeland, was stripped of his Soviet citizenship and granted asylum in the USA. He continued to represent the Ukrainian Helsinki Group from exile and remained a voice for those persecuted in the Soviet Union until his death in 1987.
} 
On the other axis of the spatial-temporal image of the city are the debates on Iurii Shevelov's commemorative plaque in Kharkiv. ${ }^{19}$ A Kharkiv native and a prominent scholar, Shevelov contributed to the study of Ukrainian culture and identity. He argued against creating a dichotomy between language and identity and was careful to withdraw from imperial, Russian-centric "intellectualism" in favour of developing a self-sufficient Ukrainian "national" identity. Curiously, his memorial plaque was barbarically removed by people who claimed that they were defending Kharkiv from "fascism." Apparently, in Kharkiv, not all people have reached the same conclusions regarding the controversial program of "deCommunization." Some communities continue to accept the nationalist historical retrofitting promoted by the former director of the Ukrainian Institute of National Memory, Volodymyr V"iatrovych, and the uncritical Stepan Bandera cult, ${ }^{20}$ while others are willing to live with Iurii Gagarin murals. ${ }^{21}$ The latter suggests that efforts to keep names and images of

${ }^{19}$ In 2013, the plaque on the building at 17 Sums'ka St. commemorating the eminent Ukrainian philologist Iurii Shevelov, who had previously lived in the building, was destroyed. A campaign was initiated based on the foul slander and defamatory comments of the Head of the Kharkiv Regional Administration, a Ukrainian politician and former governor of Kharkiv Oblast, Mykhailo Dobkin, that contained false allegations against Shevelov, accusing him of "aiding the fascists" and collaborating with the Nazis in World War II. The result was the demolition of the plaque by an unknown group of strangers. Shevelov was a professor at Harvard and at Columbia University, a foreign member of the Ukrainian Academy of Sciences, president of the Ukrainian Free Academy of Sciences in the USA, and a member of the American Linguistic Society and of the Polish Institute of Arts and Sciences in the USA. He received honorary PhDs from the University of Lund, Sweden, the V. N. Karazin National University of Kharkiv, and the National University of Kyiv-Mohyla Academy. ${ }^{20}$ Bandera led Ukrainian nationalist forces against both German and Soviet troops during World War II and even headed an armed struggle against Soviet rule in Ukraine into the 1950s. Ukrainian president Viktor Iushchenko's posthumous designation of Bandera as a Hero of Ukraine triggered intense and polarized debates in Ukraine and abroad about WWII-era Ukrainian nationalism and its place in history. ${ }^{21}$ Since 2013, one of Kharkiv's central avenues, Gagarin Avenue, has been decorated with a mural of Gagarin by Andrii Pal'val'. This was the theme of the first contemporary art festival in Kharkiv, called the "Gagarin Fest." The name of the festival, according to the organizers, was chosen because the name of Gagarin and Gagarin propaganda closely correlated to the cult of the "new man" and to the relative importance given to culture in the Gagarin celebrations during the Soviet period. Gagarin's image still reflects the political imperatives and ideological currents at work within the Soviet system. The festival program included interactive promotions, online painting, performances, an exhibition of contemporary artists, and, of course, street-art. This festival took place between October 30 and November 7, 2009. 
socialist icons are part of a politically motivated campaign to encourage nostalgia for the Soviet past. The bitterness of this debate reflects the fact that in Kharkiv the task of renaming the streets is fraught with political danger. To offer one more example, while the façades of many buildings in Kharkiv are covered with banners painted blue and yellow the national colours), red and black logos can be seen here and there on the most notorious nationalistic Right Sector's kiosks, where paramilitaries recruit volunteers to defend Ukraine.

The major trend has been a shift from political consciousness (loyalty to the Soviet Union) to a greater emphasis on the Ukrainian language and ethnicity. Younger generations know the Ukrainian language in increasing numbers, but views of history, especially regarding World War II, and attitudes toward Russia's past and present still differ markedly between ethnic Ukrainian and Russian populations. In spite of the general peacefulness of ethnic relations, any meaningful integration of the two major nationalities in Kharkiv remains incomplete, as graphically demonstrated in the cases of Shevelov's plaque in 2013 and Marshal Zhukov's statue demolishing in May 2019.

\section{CONTEMPORARY OFFICIAL STREET ART}

Today's urban landscape in Kharkiv has emerged out of a deadly stagnation. Soviet-era imagery has been slowly disappearing into oblivion, while the street art movement in Kharkiv is gaining momentum. Street art has grown from a form of indistinct graffiti to one of respectable culture. Graffiti turns one-way communication into an interchange of ideas and images. In many ways, the meaning of graffiti of all types is related to its temporary location (Cresswell) and relies on a complicated interplay between the pre-existent urban landscape and the message that neatly slips into the nexus of perception and consumption. Kharkiv has become famous for its street art festivals, which have been held by the Municipal Gallery beyond just "language-in-use" and the meanings it conveys. Kress and van Leeuwen incorporate the notion that visuality is part of language, calling attention not only to the meanings delivered by languages but also to visual aspects such as typography, placement, the semiotic layout, colour, and spatial and kinetic arrangements.

An intended shift is manifested in the new Mural Project that entails an adaptation to national circumstances. Recently, the Mural Social Club, in collaboration with UNICEF Ukraine, invited French street artist and activist Julien Malland, who, along with Oleh Sosnov from the Sky Art Foundation, painted the façades of schools, nurseries, and other buildings near educational institutions in Kyiv, Odesa, and Kharkiv. The murals aimed to 
give children the opportunity to experience art as a part of their everyday life and to hone their ability to think spatially. Another social art project implemented locally is a series introducing the murals of great Ukrainians: important historical figures created by Andrii Pal'val' and the creative group Kailas-V (Sokolynska). However, the fact that public space is primarily shaped by public authority makes it an arena for manipulation of public practices. While there is no way to know precisely how accountable the new street art movement has been to the Kharkiv local government and its flamboyant mayor, there seems to have been a desire by the city's art businesses to defer to a nostalgia for the socialist Soviet past. The murals depict honorary Kharkiv citizens and Soviet movie stars such as Liudmila Gurchenko, Nataliia Fateeva, Klavdiia Shul'zhenko, and Leonid Bykov. These characters-in socialist art style fashion-are all equipped for the bright future. The murals' backgrounds are stylized meadow lawns blending seamlessly into a cloudless sky, ablaze in exploding fireworks. This street art, national in form and socialist in content, is full of the recurring themes of workers on tractors and peasant girls with flower wreaths with multicoloured ribbons attached to the back. The severe artificiality of the tones is exceptional for this street art, the colours chosen not as a reflection of nature, but to elicit an emotional response. Pal'val"s entire oeuvre, which consists of more than a hundred murals, illustrates a fearlessness when it comes to colouration. He experiments with the astute manipulation of natural elements: particularly, faces often take on monstrous tones of green, yellow, or blue, and combinations of opposing but equally bright coloursthe "simultaneous contrast" of reds, blues, oranges, and greens causes an optical vibration that heightens the surrealistic context of his works.

In addition, a great number of artists have entered the public urban space with unauthorized art performances. It is not, however, former nonconformist artists who have become interested in performing in the streets and squares, but those who choose to perform in site-specific performances, where the historical and political significance of a given place conditions the potential meaning of the performance. The Taras Shevchenko statue, with its proximity to the V. N. Karazin National University of Kharkiv, is loaded with historical and political meanings and has become the most significant and most contested site. ${ }^{22}$ During Soviet times, KGB officers

\footnotetext{
${ }^{22}$ An example of activist efforts to support people speaking Ukrainian is the folklore group "Muravs'kyi shliakh," led by Halyna Luk"ianets'. The group members have collected, studied, and performed folk and ritual songs of eastern Ukraine (Sloboda and Poltava regions). It deserves its reputation as one of the most popular ethnographic groups in Ukraine. When I asked them during an interview, why they devote so much time to their performances and value their group, almost all them said that it was due to their broad interest in Ukrainian culture and family
} 
would monitor who laid flowers at the Shevchenko monuments on March 9 of every year (to celebrate Shevchenko's birthday) all around Ukraine, as it was considered nationalist and anti-Soviet for activists to go with flowers to the Shevchenko monuments. In a post-Maidan Kharkiv, Kharkivites have been gathering near the Shevchenko monument every November 19 to celebrate the anniversary of the Maidan.

The graffiti of Aleksandr Pushkin on Pushkins'ka St. (see Figures 9, 10) and Mykola Hohol' (Nikolai Gogol') on Hohol' St. (see Figures 11,12) in the street-art interpretation by Roman Minin and Hamlet Zyn'kovs'kyi are particularly illustrative examples of the changing nature of visual communication between art and audience in an urban environment and the driving force and the recognizable symbols of local and national identities. ${ }^{23}$

connections to the Cossacks-their grandparents trace their lineages to the Sloboda Cossacks (Luk'ianets'). These responses signal their desire for equal representation and social inclusiveness in the diverse musical market of Ukraine.

${ }^{23}$ Some graffiti have been removed or destroyed since I photographed them. 
Figure 9. Pushkin's Duel. Graffiti. Kharkiv, 2008. ${ }^{24}$

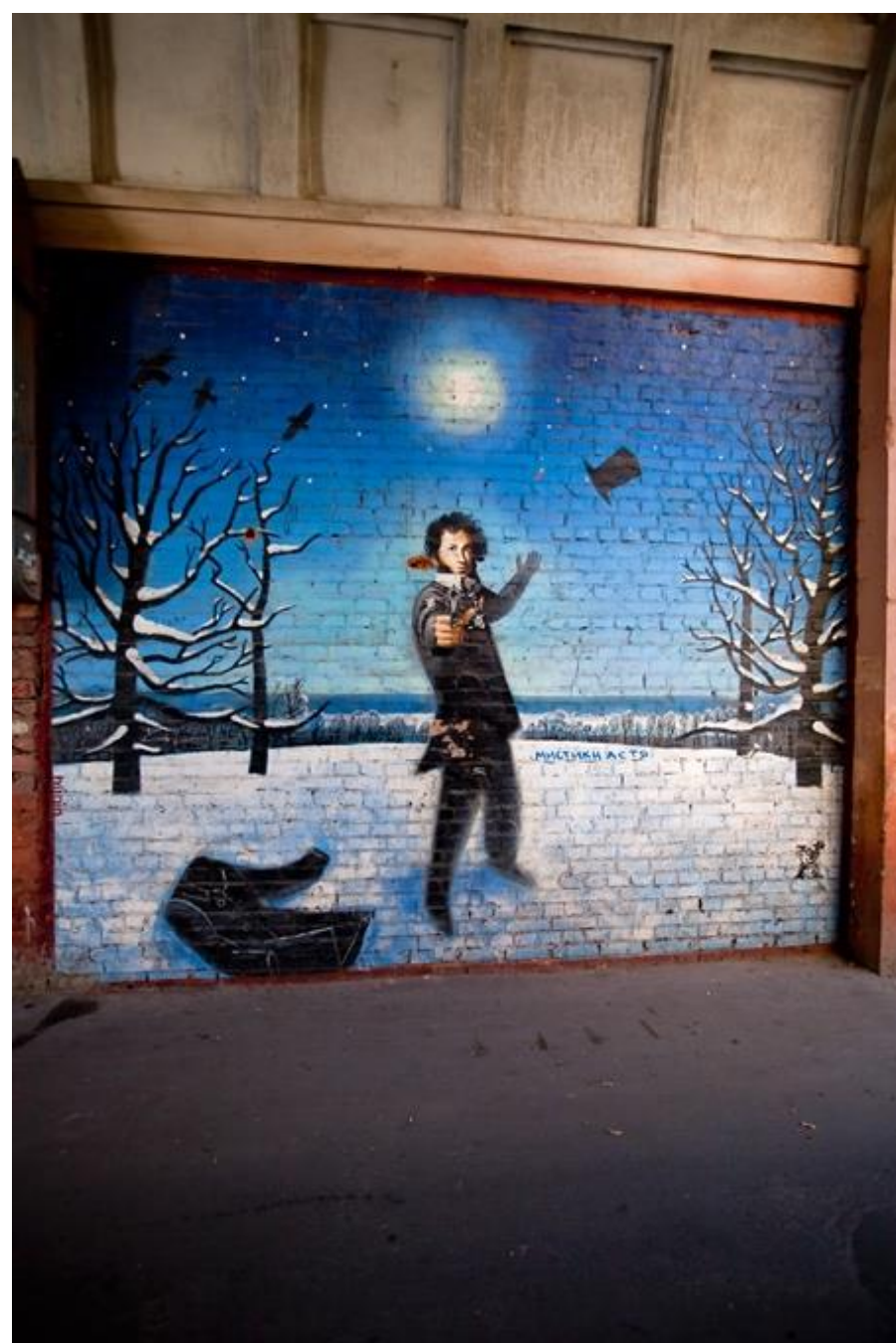

${ }^{24}$ Source:

https://ru.wikipedia.org/wiki/\%D0\%A4\%D0\%B0\%D0\%B9\%D0\%BB:\%D0\%9F\% D1\%83\%D1\%88\%D0\%BA\%D0\%B8\%D0\%BD\%D1\%81\%D0\%BA\%D0\%B0\%D1\% 8F $69 \%$ D0\%9F\%D1\%83\%D1\%88\%D0\%BA\%D0\%B8\%D0\%BD \%D0\%B3\%D1\% 80\%D0\%B0\%D1\%84\%D1\%84\%D0\%B8\%D1\%82\%D0\%B8.jpg\#filehistory.

Accessed 12 Nov. 2019.

(C) 2020 East/West: Journal of Ukrainian Studies (ewjus.com) ISSN 2292-7956

Volume VII, No. 1 (2020) 
Figure 10. Pushkin. Graffitti. Kharkiv, 2008. Photo courtesy of the photographer, Aleksandr Zarajsky.

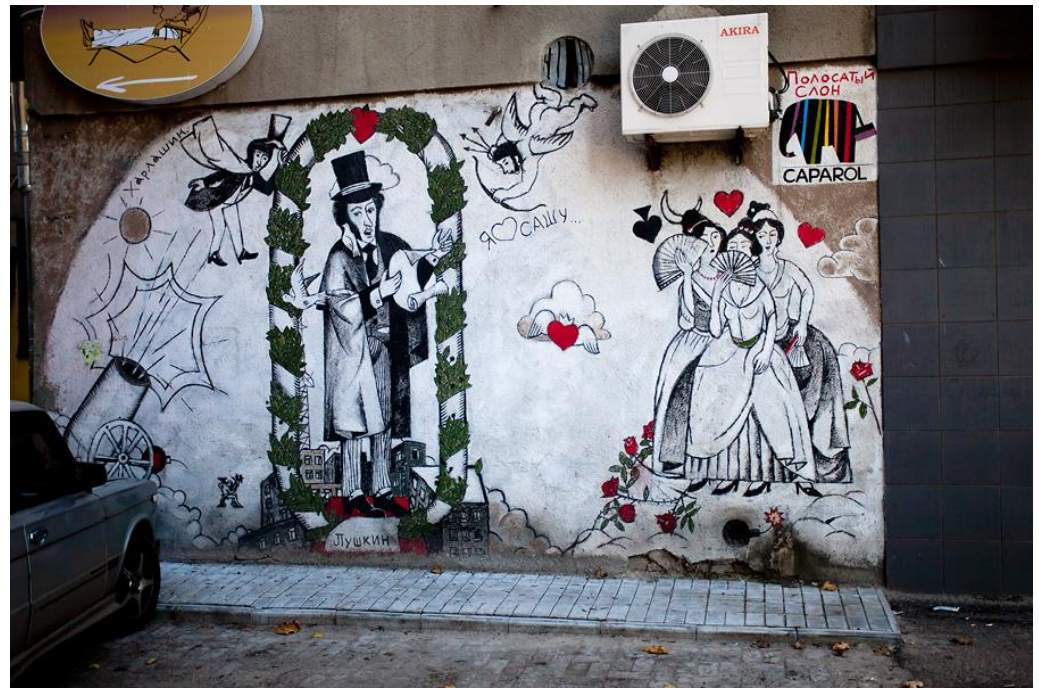

Figure 11. Mykola Hohol' (Nikolai Gogol'). Graffiti. ${ }^{25}$

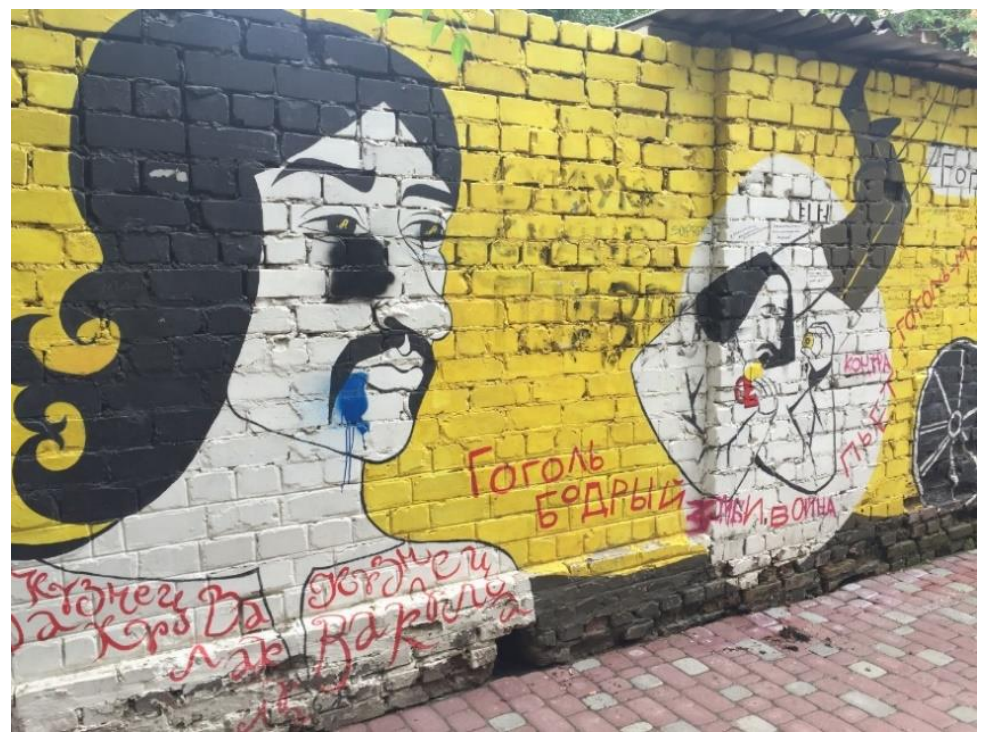

25 Source: https://mykharkov.info/news/strit-art-po-harkovski-iskusstvo-nastenah-s-izyuminkoj-66977.html. Accessed 20 Nov. 2019.

(C) 2020 East/West: Journal of Ukrainian Studies (ewjus.com) ISSN 2292-7956

Volume VII, No. 1 (2020) 
Figure 12. Mykola Hohol' (Nikolai Gogol'). Graffiti. ${ }^{26}$

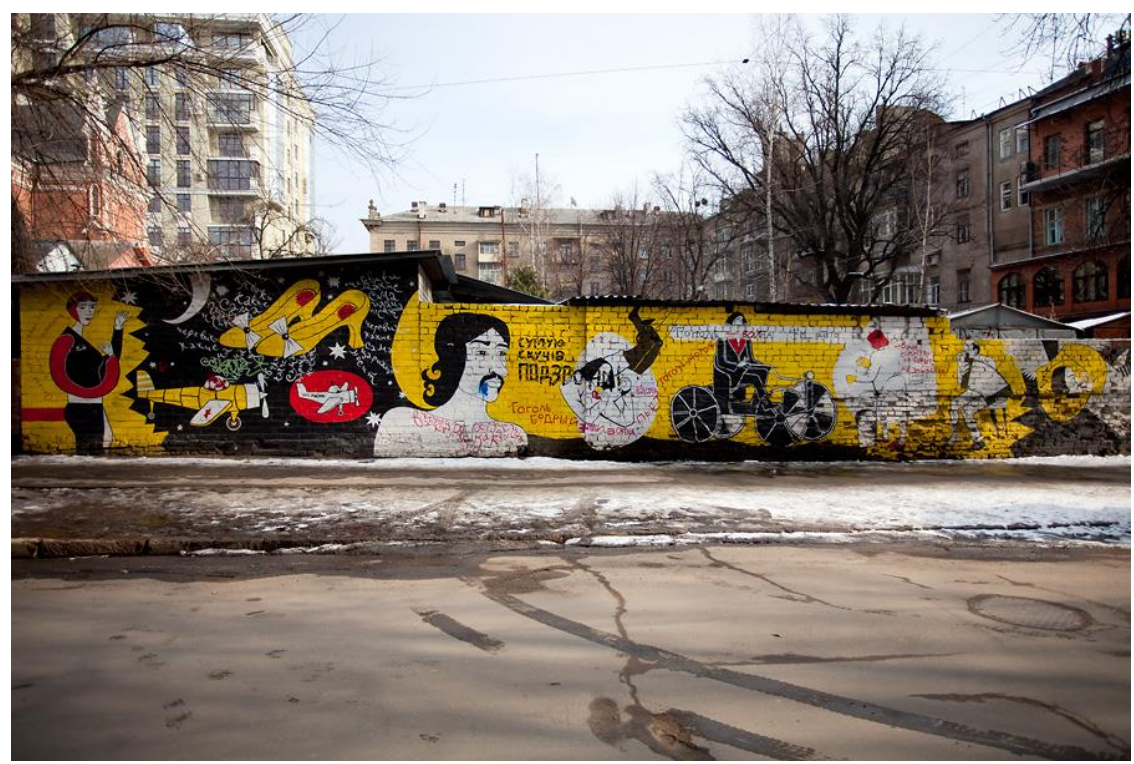

Minin's graffiti works were full of parody and ridicule of Pushkin's dramas. This contemporary version of a Pushkin memorial does not show passersby the scholastic cliché of "the great Russian poet," but depicts a real, living man. The "anti-heroism" of this work is an important feature of Kharkiv street art and has led to the inclusion of Pushkin in the discursive field of public art. Whether the paradoxical return of kitsch aesthetics means a rupture with Soviet nostalgia is unclear, but apparently, the younger generation has put forth a challenge to the discourse of Russianness, and displays clear disillusionment with the intellectual milieu of high Russian culture, stressing instead the personal memories linked to the great poet. The function of the parody is not only to negate and mock the tradition, it is also to adapt it to the contemporary context. As Zaiets candidly observed:

These paintings have great artistic value based on their smart composition, rich colors, and good graphics. But they are still more remarkable because they fluidly articulate the specific cultural game that Rosalind Krauss called the "optical unconscious." Thus, through the tactics of "coup," the meanings of the wall paintings frame "Pushkin," "Gogol," "Kharms," and "Tolstoy" in unusually egalitarian contexts. These classical figures of literature are more

26 Source: https://mykharkov.info/news/strit-art-po-harkovski-iskusstvo-nastenah-s-izyuminkoj-66977.html. Accessed 20 Nov. 2019. 
comedic, irrational, and prosy than monumental. Cheerful, straightforward idioms transfer images directly to the consciousness of passersby (281).

\section{ThE CASE OF HAMLET ZYN'KOVs'KYI, THE KHARKIV STREET ART ARTIST ${ }^{27}$}

Recently, local street artist, Hamlet Zyn'kovs'kyi, colloquially known as Hamlet, has become quite the city celebrity. He paints his images on crumbling concrete or brick walls, ugly metal gates and garage doors, in arch entrances to the old courtyards of residential buildings, and in closed yards of old houses in the historic part of the city. He produces art on canvas and metal as well as photographs and installations. In other words, he is somehow managing to straddle the commercial, artistic, and street art worlds. Zyn'kovs'kyi's name is "Hamlet" ("Gamlet") (that is, "Gam let" or "Shum let" in Russian, "Ham rokiv" in Ukrainian) and refers to the noise of time. ${ }^{28}$ Responding to the question of why he paints on the streets, he answers that "I sees my beloved downtown streets and courtyards as my own studio where I would like to leave my works for those walking around the city" (Zyn'kovs'kyi, interview, 3 Jan. 2019). ${ }^{29}$ What is so unique about this artist and his works are his images that are not intended to shock or delight, but to provide moments of reflection, and are suggestive of distinctive nostalgia. He seems to reflect on everyone's need to communicate what is on their mind, such as anxiety. As one of his typical faceless characters says in one of his graffiti, "You are not mine. Yes, I am mute" 30 (see Figure 13).

\footnotetext{
27 A Google map of Hamlet's street art was created by his fans and can be seen at https://www.google.com/maps/d/viewer?mid=1f4yPZcwPAu7TotG3Rfly1yPDOKI $\&$ hl $=$ ru \&ll $=50.03270368637665 \% 2 C 36.26174925000009 \& z=11$. Accessed 12 Nov. 2019.

28 The phrase alludes to a title of collected prose works by one of Russia's towering literary figures, Osip Mandel'shtam. However, it does not mean that Hamlet has intentionally alluded to this source.

29 These quotes and the others that follow are English translations based on the original recorded Russian-language interviews.

${ }^{30}$ In Russian, we can see the pun on "nemoi" ("silent") versus "ne moi" ("not mine"). The bitter line, where the word "nemoi" takes on the additional connotation of "mute," does not spoof the trivial nature of non-belonging so much as it trivializes the idea of active citizenship. The phrase has lost its sense of pathos and has become an ironic reference to the lack of involvement in the local communities and in democracy at all levels.
} 
Figure 13. Graffiti by Hamlet Zyn'kovs'kyi. Photo courtesy of the photographer, Ivan Ponomarenko.

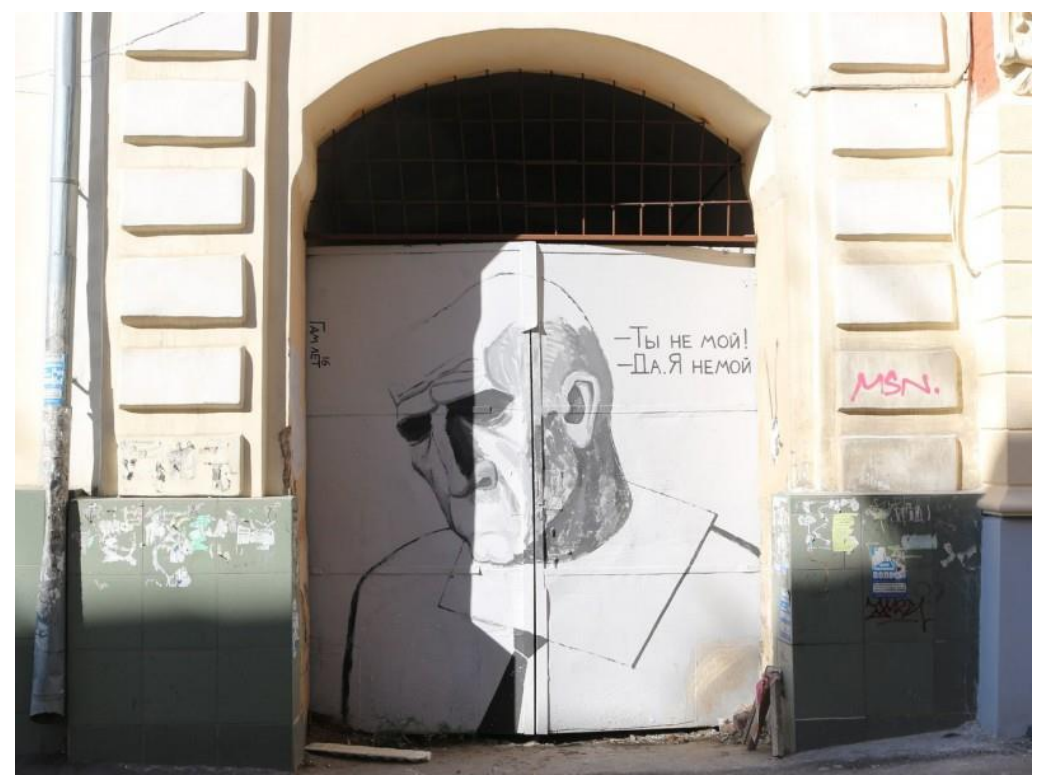

As he often does in his graffiti, Hamlet paints a large-scale faceless human figure cut off by the edges of buildings or turned completely away from the viewer, as if looking out into the world or witnessing something the viewer cannot see. The figures are somehow connected to the dystopian environment in which they are revealed. In his graffiti shown in Figures 14 and 15, words "Tune in," and "Opinions" are an appendage to what has actually taken place. We also sense a self-reflexive criticism, but the content of the message has the illocutionary force of alarming, not of denouncing or condemning. The message is rendered in bold capital letters, indicating the magnitude of the situation, to persuade the audience to agree with the intended message: With the world knowing about the political situation in the country, Kharkivites must be more outspoken, and Kharkiv must have its own civil movement. Hamlet's artistic position is most evident in the following statement: "Graffiti made me feel better about myself, gave me a voice, but it also reaches out to the audience. My works are open for dialogue, and dialogue is taking place. I could have written a book about accidental connections with fans who shared how they reacted to my works" (Zyn'kovs'kyi, interview, 3 Jan. 2019). 
Figure 14. Graffiti by Hamlet Zyn'kovs'kyi. Photo courtesy of the photographer, Ivan Ponomarenko.

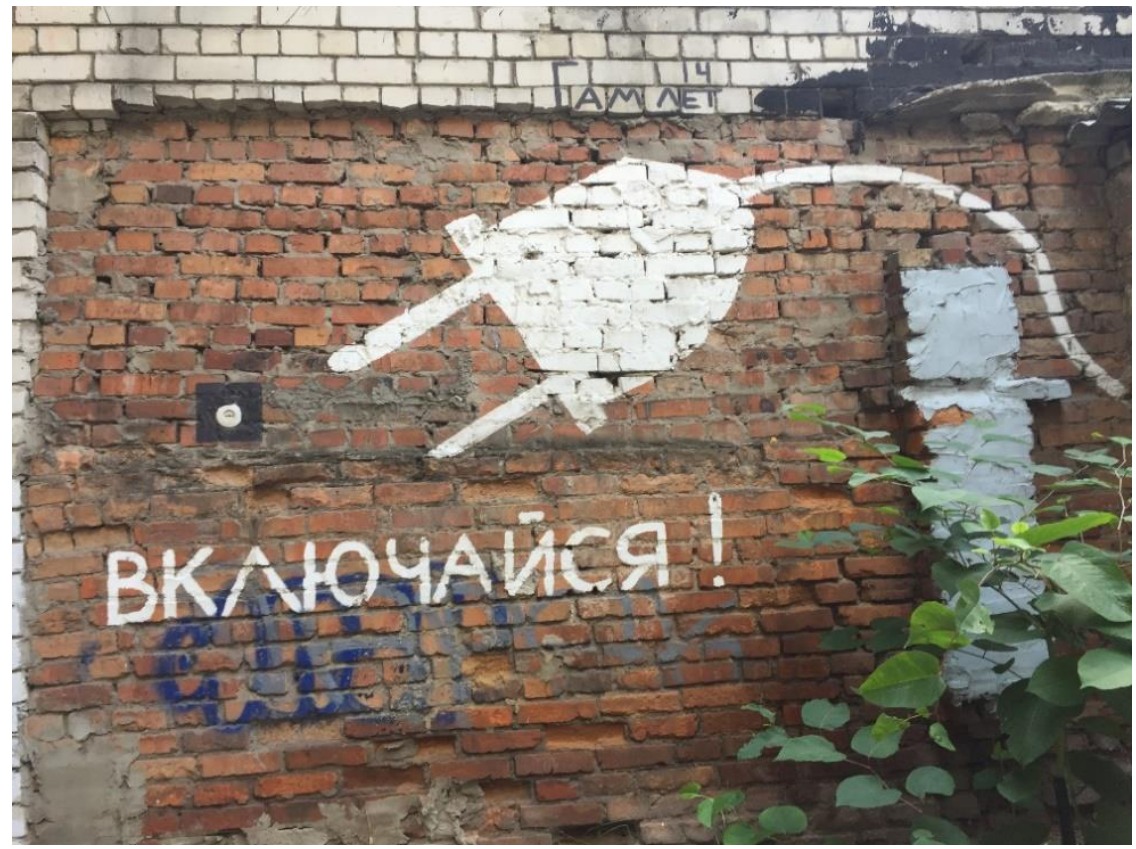

Figure 15. Graffiti by Hamlet Zyn'kovs'kyi. ${ }^{31}$

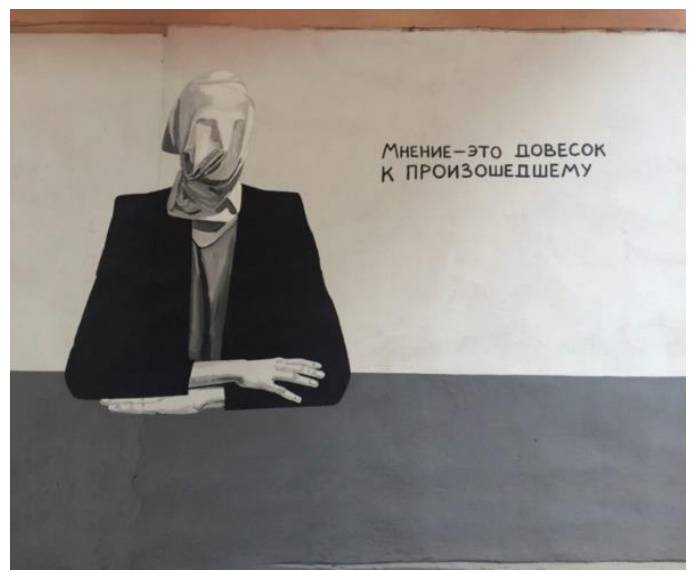

31 Source: https://kharkivobserver.com/street-art-in-kharkiv/. Accessed 12 Nov. 2019.

(C) 2020 East/West: Journal of Ukrainian Studies (ewjus.com) ISSN 2292-7956 Volume VII, No. 1 (2020) 
Hamlet's response shows a very powerful stance. He has customized the city, reclaimed it, and made passersby smile and feel optimistic. He wants to see them united, sharing common dreams and ownership of their favourite yards and walls of Kharkiv. He has already become an inseparable part of Kharkiv and has contributed to its unique atmosphere. It is primarily Hamlet's earliest works, from the series Naedine s soboi (Alone With Self/On One's Own), included in the 53rd Venice Biennale, that revealed his response to and affinity for the Stoic philosophy of Marcus Aurelius. The secondcentury Roman emperor wrote to and for himself. As his Meditations show, Aurelius's philosophy had a practical dimension as it provided spiritual exercises for living, i.e., he created a set of rules to live one's life with serenity and resilience, which remain as relevant now as they were two thousand years ago. Many of Hamlet's often subversive graffiti dicta reflect the far-off echoes of his favourite philosopher's meditations.

For Hamlet, as for Michel de Certeau, urban space is neither fixed nor stable, and no proper official version of the city exists. Hamlet aims to ask questions of public space by confronting passersby with symbols, jarring their consciousness, making the familiar (and thus the unnoticed) strange and worthy of attention. Nobody pays to see them, and they are not "expected." This conception of public space may be seen as a dichotomy between power and resistance, structure and agency, which divides the space of the city in two: the city structure versus the street (Massey). The street is here seen as the characterization of the everyday, as if removed from the city and epitomized by Hamlet's creative power. Again, this effect is both an apparent presence and an invitation to act, to see through the walls what happens inside the homes. One of his series is entitled "rain project," or what I call "walls of inspiration and influence." He paints in the arched entries to courtyards, and his audience, when it is caught in the rain, stands in these tunnel entries surrounded by his works with captions like "Other shores are nearby," "There is a time for everything, said the Captain of the Zeppelin," "The Last Supper lingers on, only now without any participants" (see Figures 16,17). 
Figure 16. Graffiti by Hamlet Zyn'kovs'kyi. Courtesy of author.

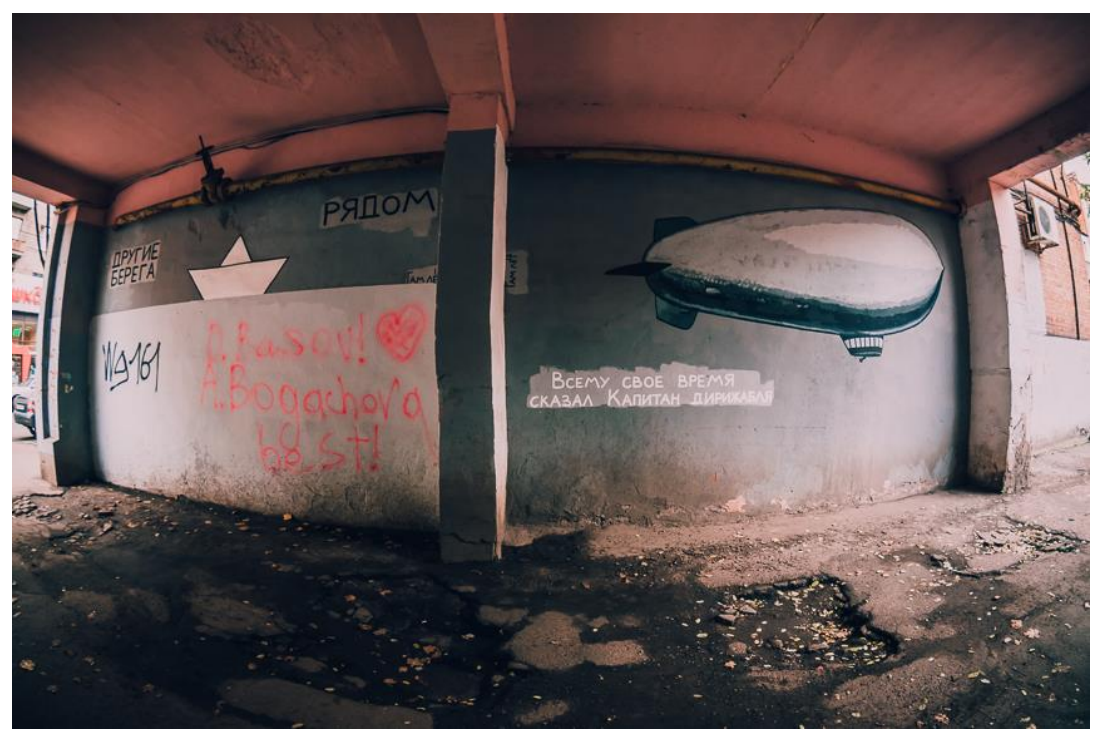

Figure 17. Graffiti by Hamlet Zyn'kovs'kyi. My photograph.

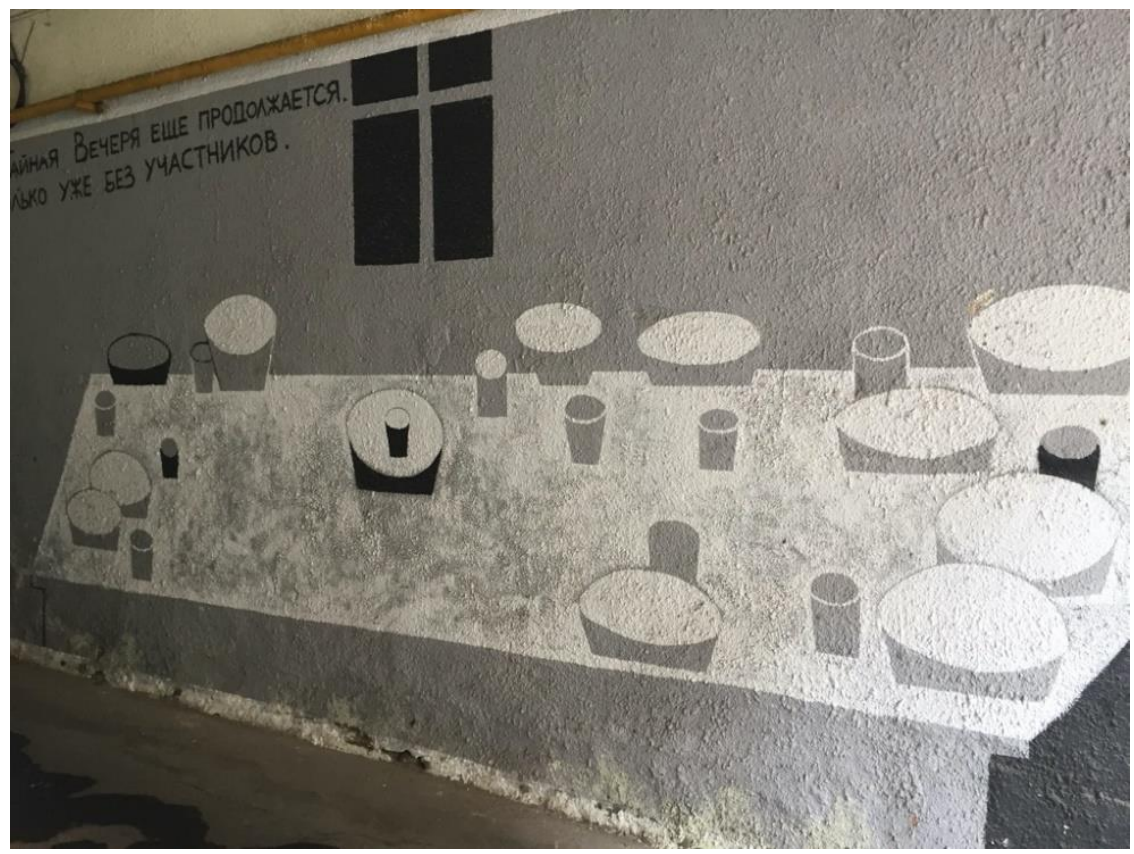

(C) 2020 East/West: Journal of Ukrainian Studies (ewjus.com) ISSN 2292-7956 Volume VII, No. 1 (2020) 
In Hamlet's statements, the most unexpected, clever, and tricky questions of human life are posed, and we see the conflation of philosophy with its mode of practice. Noticing that the locations of these philosophical musings have shifted from private gatherings to more public mediums, one can assume that street art is viewed as a "way of life" or "state of being," like in the following graffiti: "He said that life is a path. Friends are regular fellow travellers. Coffee tastes better without sugar. Fear is just a doubt. Love is the only engine. Pigeons need to be fed in the morning" (Figure 18). In this sense, street art is viewed not as a profession, but as an activity. Bright, wellarticulated, original ideas do not necessarily help to pay the bills or bring prestige. It is not "practicing art" that matters, but the act of street art per se.

\section{Figure 18. Graffiti by Hamlet Zyn'kovs'kyi. Courtesy of author.}

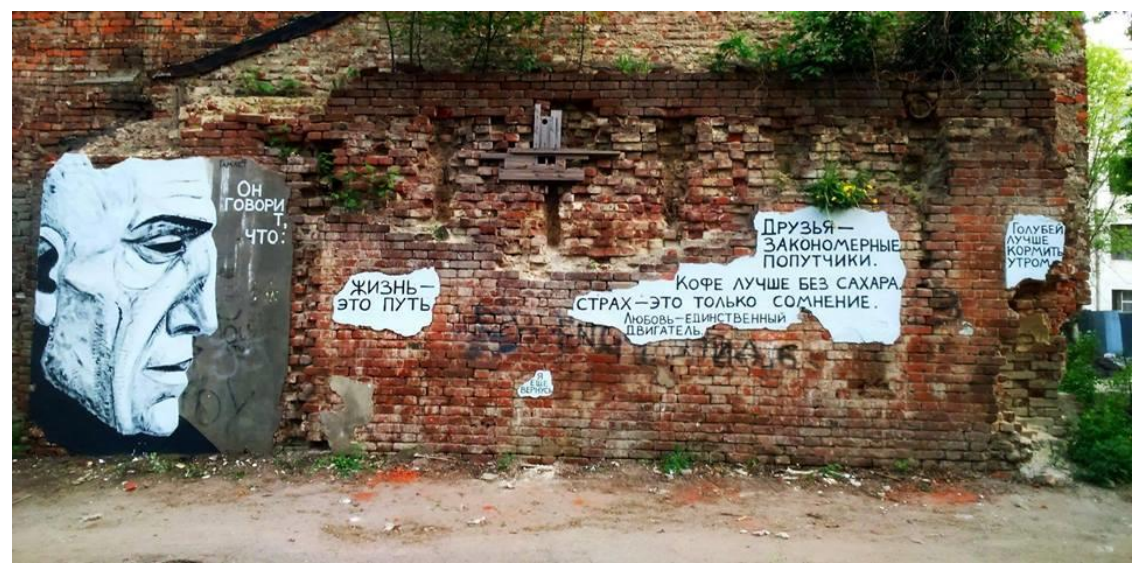

Evident in all of Hamlet's graffiti is a sense of playfulness and an openness to experimentation. Often humorous and psychologically complex, they display a confident autonomy from the dictates of commissioning themes and motifs. "I'm just a flyby" (Figure 19), "A scooter is not a means of transportation, it's a personality feature" (Figure 20). What is significant is the diversity of graphic solutions employed, indicating a high degree of personal expression and a genuine affection for the city. 
Figure 19. Graffiti by Hamlet Zyn'kovs'kyi. Courtesy of author.

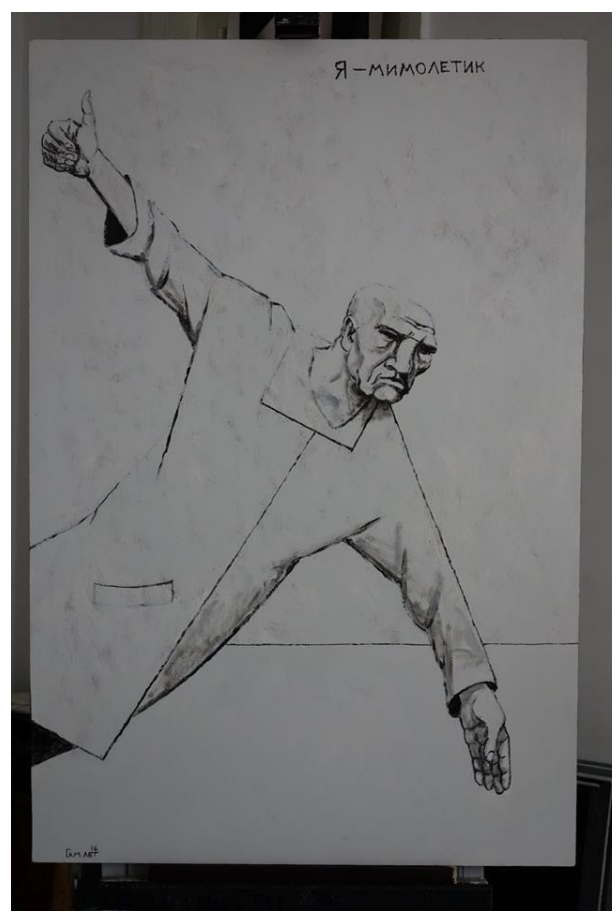

Figure 20. Graffiti by Hamlet Zyn'kovs'kyi. Courtesy of author.

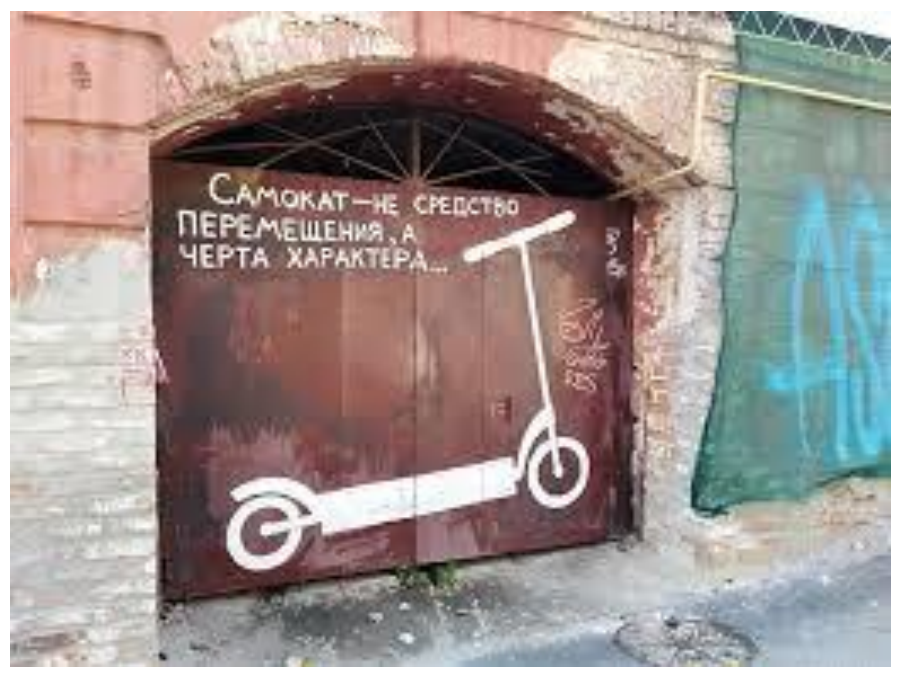

(C) 2020 East/West: Journal of Ukrainian Studies (ewjus.com) ISSN 2292-7956 Volume VII, No. 1 (2020) 
In another one of his graffiti, a figure that comes more sharply into focus as it "approaches" the foreground enhances the temporal quality of the image, while a depiction of a large crowd with a few identical characters creates a depth of field through the gradual reduction of their scale: "Everybody was chasing glory ("slava"), but Slava couldn't care less" (Figure 21). ${ }^{32}$ Here, the repeated images evoke an idea of ritual-centred aspects of everyday experience.

Figure 21. Graffiti by Hamlet Zyn'kovs'kyi. Courtesy of author.

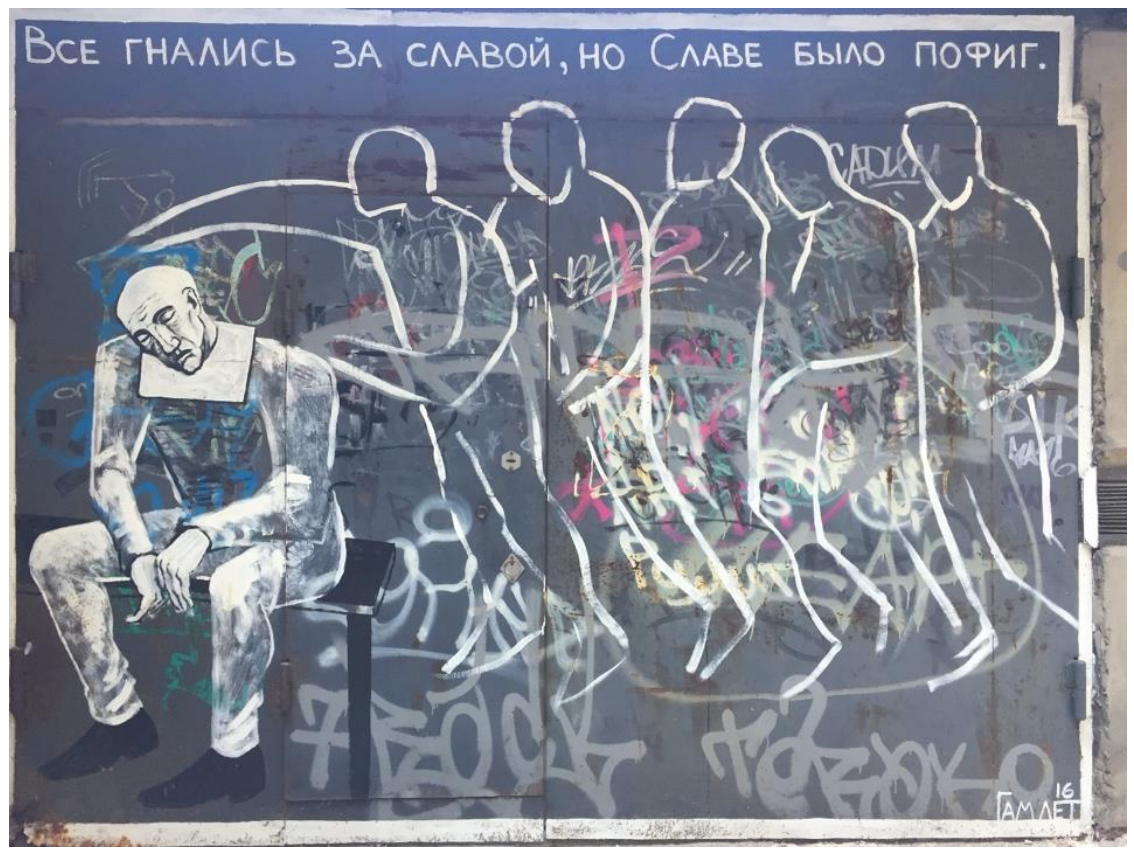

The text font used in graffiti is almost exclusively blocky, sans-serif, and mechanical in appearance. As clarity is paramount in graffiti, the legibility of letterforms does not, however, connote a dullness of composition. On the contrary, Hamlet's use of letterforms is lively and innovative. Words or sentences become structural elements, as in "Life is a path" (see Figure 18).

Hamlet's facile manipulation of pictorial space seems remarkably prescient. Another convention Hamlet exploits is a futurist-like ombre, or shadowing, at the edges of forms to indicate volume. At other times, figures are mere silhouettes in surrounding areas of highlights. He is equally

32 In Russian, the pun is based on the homonyms of "glory" and the name "Slava." 
innovative in his use of black, white, and grey paints, particularly as a background. His graffiti are expressive in character, with sharply contrasting areas of light, evoking the experience of viewing a scene through the window if you are outside in the dark. The consequence of the employment of these techniques is an emphasis on the components of the human experiencefear, pathos, humour, anxiety, dismay (see Figures 22, 23, 24, 25-"This is the absence of my presence," "I know what I live for," "In this game, you can be any piece you want, as long as you follow your own rules," "I knew an old man who knew nothing and was absolutely happy").

Figure 22. Graffiti by Hamlet Zyn'kovs'kyi. Courtesy of author.

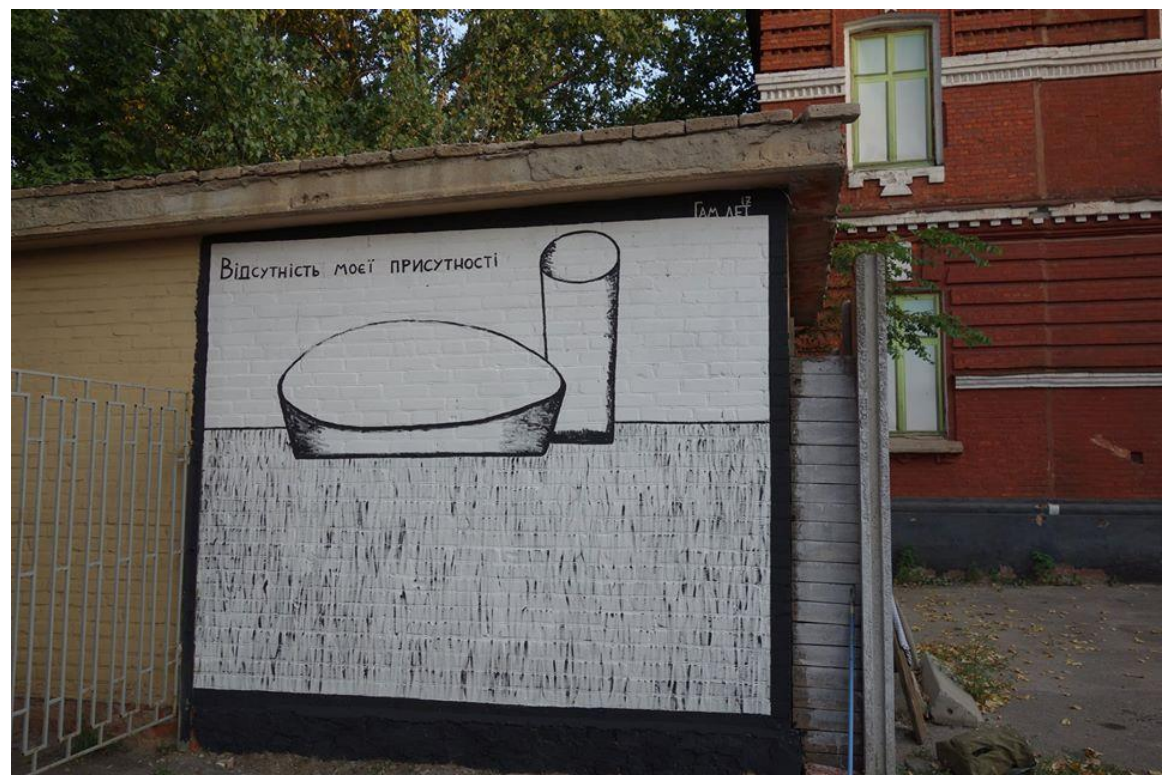


Figure 23. Graffiti by Hamlet Zyn'kovs'kyi. Courtesy of author.

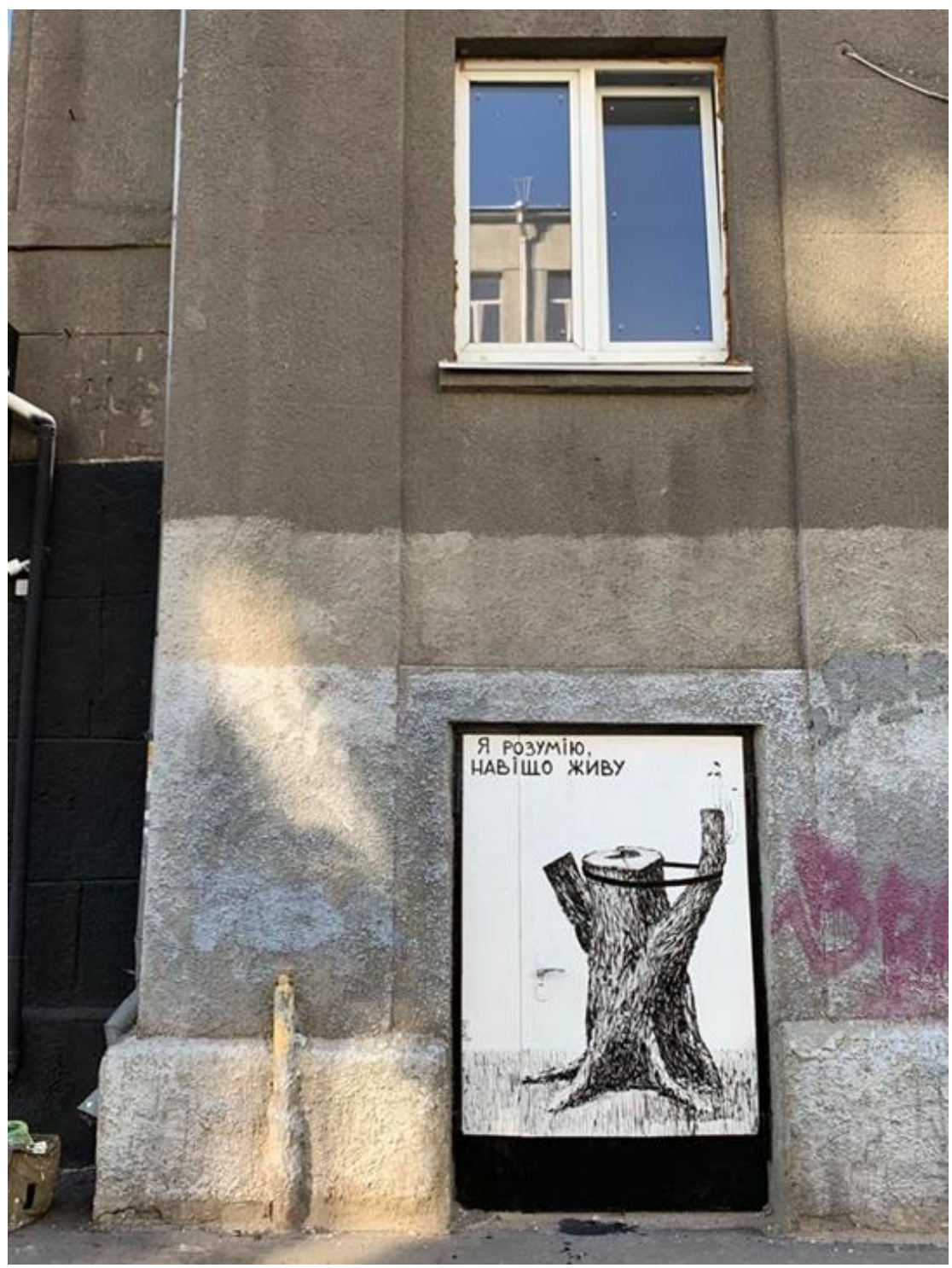

(C) 2020 East/West: Journal of Ukrainian Studies (ewjus.com) ISSN 2292-7956

Volume VII, No. 1 (2020) 
Figure 24. Graffiti by Hamlet Zyn'kovs'kyi. Courtesy of author.

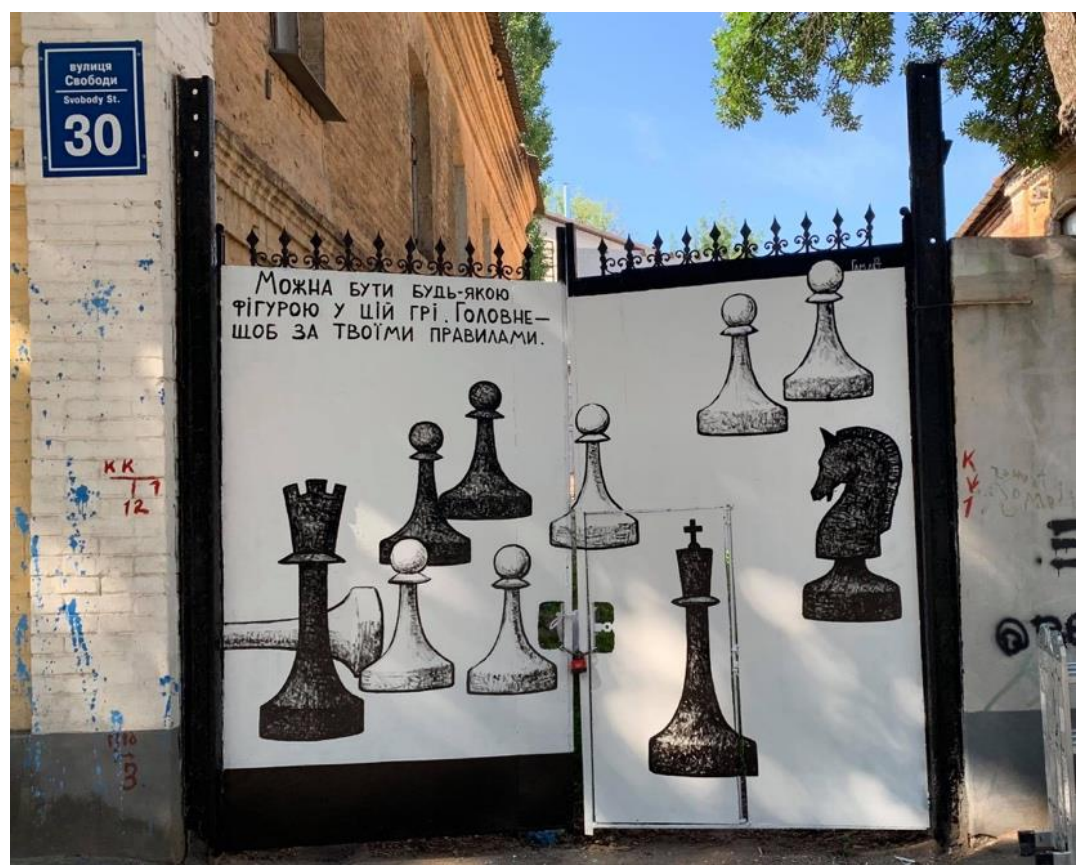

Figure 25. Graffiti by Hamlet Zyn'kovs'kyi. Courtesy of author.

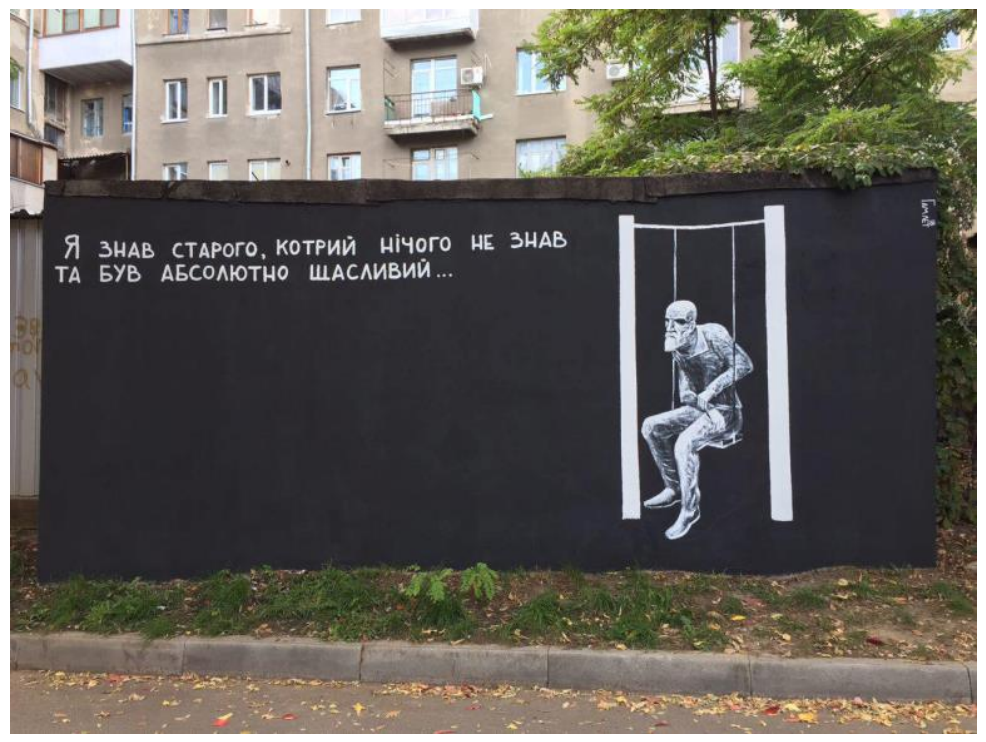

(C) 2020 East/West: Journal of Ukrainian Studies (ewjus.com) ISSN 2292-7956 Volume VII, No. 1 (2020) 
Hamlet likes getting feedback on his graffiti and seeing messages left for him that are painted over his own image or added to it. Sometimes these reactions make him think again and focus on controversy. In September 2018 , one of his graffiti works on an electricity substation wall that had been there for two years - a painting of a man standing in the palm of a huge hand, with the caption: “It appears I've found myself, let's hope I don't get lost again" (Figure 26) - was painted over with dark grey paint. After the mural was painted over, every other night a new graffiti work appeared on the freshly painted grey wall, some of them more creative than others. One day, a big cartoon Jesus was drawn on the wall, asking in a speech bubble, "Are you going to paint over me as well?" Another day, a window appeared with the caption, "A window onto a grey world," while the next day, a Hamlet fan left the line, "The wall wants a beautiful new tattoo," which was also covered up with the same grey paint. This episode illustrates the power of images and the nature of words that are fleeting and transient. Hamlet's art should thus not be seen to provide us with answers to what is the "true" meaning of urban space, but rather it should be seen as a way of questioning space and opening it up for us to see connections or disconnections that cannot always be deduced rationally from the givens.

Figure 26. Graffiti by Hamlet Zyn'kovs'kyi. My photograph.

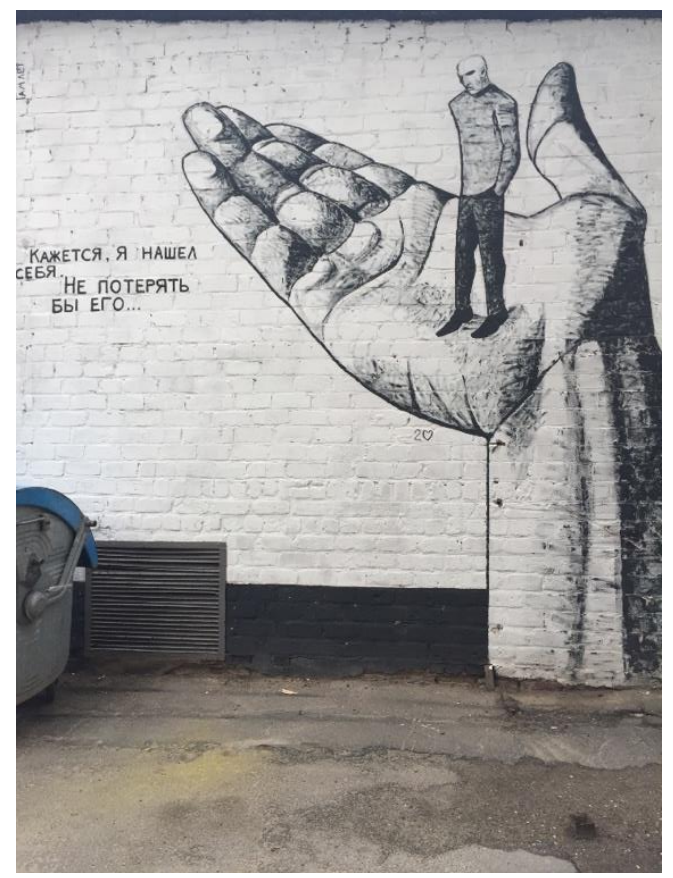


One of the great projects performed by Hamlet in collaboration with Serhii Zhadan, a literary icon of contemporary Ukrainian literature, ${ }^{33}$ was an art book, Antena (Antenna), which consists of eighty verses united by one cover. It includes Biblical quotations and newspaper chronicles, intimate diary entries, and church sermons. Hamlet helped to make this poetry collection one of the most profound and powerful among Zhadan's books. As Hamlet told me, he first read Zhadan's poetry book Tampliiery (Templars), where pages littered with blank space looked oddly silent to him; he wanted to leave his own visual commentaries, and he presented the hand-made copy to the author. This is how the idea of Antena was born.

Kharkiv sees its street artists as visionaries, rebels, eccentrics, and outsiders, probably because that correlates with the idea that they spend a lot of time alone doing their artwork. But Hamlet does not fit in with these long-standing stereotypes, because he is not a troubled dreamer or a footloose bohemian. Hamlet likes the urban ambience, but he is not on any social media, as he has a strong social network of friends and like-minded artists. Most importantly, Hamlet explicitly understood the function of his city graffiti projects and their remarkable innovations. While strikingly beautiful, they are clearly a means to create visually compelling work. The purpose of any graffiti is to attract the eye in the briefest of intervals. It is in this deceptively simple ambition that these complex works excel. His works, albeit of a popular genre, are revolutionary with respect to the history of the city's street art. The numerous innovations, the rethinking of the content of the wall graffiti, the introduction of implied movement, the expressive use of letterforms and monochromatic colours, the distortion of scale and perspective, make his works exceptionally keen.

Hamlet has expanded his work beyond the confines of a single city and a particular genre and techniques of graffiti. On January 1, 2019, Gamlet started a year-long graphic design project that comprised a series of graphic and pictorial works that show reflections for 365 consecutive days. 365 dnei (365 Days) tells a story of a man from Ukraine, who is not only displaying his beliefs on the current state of Ukrainian society but who realizes that the changes inside and around him depend on his choices. ${ }^{34}$

In his graphic design, Hamlet remains true to the credo of street art, and many of his graffiti pieces are manually copied on sheets of paper or polyester. In so doing, he underscores not only his years of training at Kharkiv State Academy of Design and Arts but also his attentiveness to

\footnotetext{
33 Zhadan made Kharkiv the centre of Ukrainian literary life again. His last art book, a new poetry collection Antena (Antenna), was published by Meridian Czernowitz.

34 The idea for this project came from a Ukrainian novelist, essayist, and journalist, Taras Prokhas'ko, who maintains that self-imposed rules are not constraints but good decisions made in batches.
} 
architectural forms and shapes. In these graphics on paper that emerged as a humanistic response to the harsh social reality, he uses a basic black and white colour palette and utilizes satire and irony to create resonant social messages. This calendar of daily personal reflections will be put on display at Iermylov Centre. The exhibit will examine how the tradition of city graffiti in Kharkiv evolved in terms of subject, style, and ways of seeing. This project invites viewers to experience graffiti not only as performative dynamic art, but also as static material art that involves both a prolonged engagement with the artwork as well as an active appropriation.

Certain issues concern Hamlet: for example, city authorities, political scientists, Ukrainian military men, government establishments, and others. A war in Donbas is one such issue. Hamlet has suggested that in the 365 Days series, one particular piece has a symbolic importance and reminds him of a week in August he spent in Marinka, Donbas. ${ }^{35}$ He describes a life in a war zone as follows:

Men are wearing camouflage and balaclavas and carrying Kalashnikovs; there are trenches that snake through a scarred landscape of dry barren agriculture fields and shattered buildings. I'm a civilian, and the casual cruelty kills me. But I feel if I don't come to paint for our soldier, who is coming? Where once rockets and tank shells shattered apartment blocks and rural villages, snipers are now the greatest enemy. You can hide from artillery, but not from snipers. It is a constant worry on the front line, a refrain heard at every turn: Stay low, move fast, spread out. I painted rusted gates of a former dairy farm. Through a small opening in the gates, I could peer out into no-man's land. The enemy is just 500 yards away and the Ukrainian soldiers watch for separatist snipers. (Zyn'kovs'kyi, interview, 14 Oct. 2019)

His art (Figure 27) adorns the old rusted peeling gates pierced through with shell and bullet holes. He uses the theme of scaffolding and utilizes typography. What is so striking about this work is the graffiti's message pairing nation-building with violence and offering a non-trivial insight: "We have a war to build up our country." The work also carries the message that peace comes with active hard work. The artist's interpretation turns an image of scaffolds into a metaphor of peace in a high-conflict area, amid the savagery of the Donbas total anarchy, inviting viewers to contemplate the future perspectives for themselves.

\footnotetext{
35 The Donbas, a post-industrial mining region, is located deep in southeastern Ukraine along the Russian border and is known for its regional allegiance. The dominant language is Russian, although Ukrainian is common, as is surzhyk, the name for the fusion of the two languages.
} 
Figure 27. Graffiti by Hamlet Zyn'kovs'kyi. Courtesy of author.

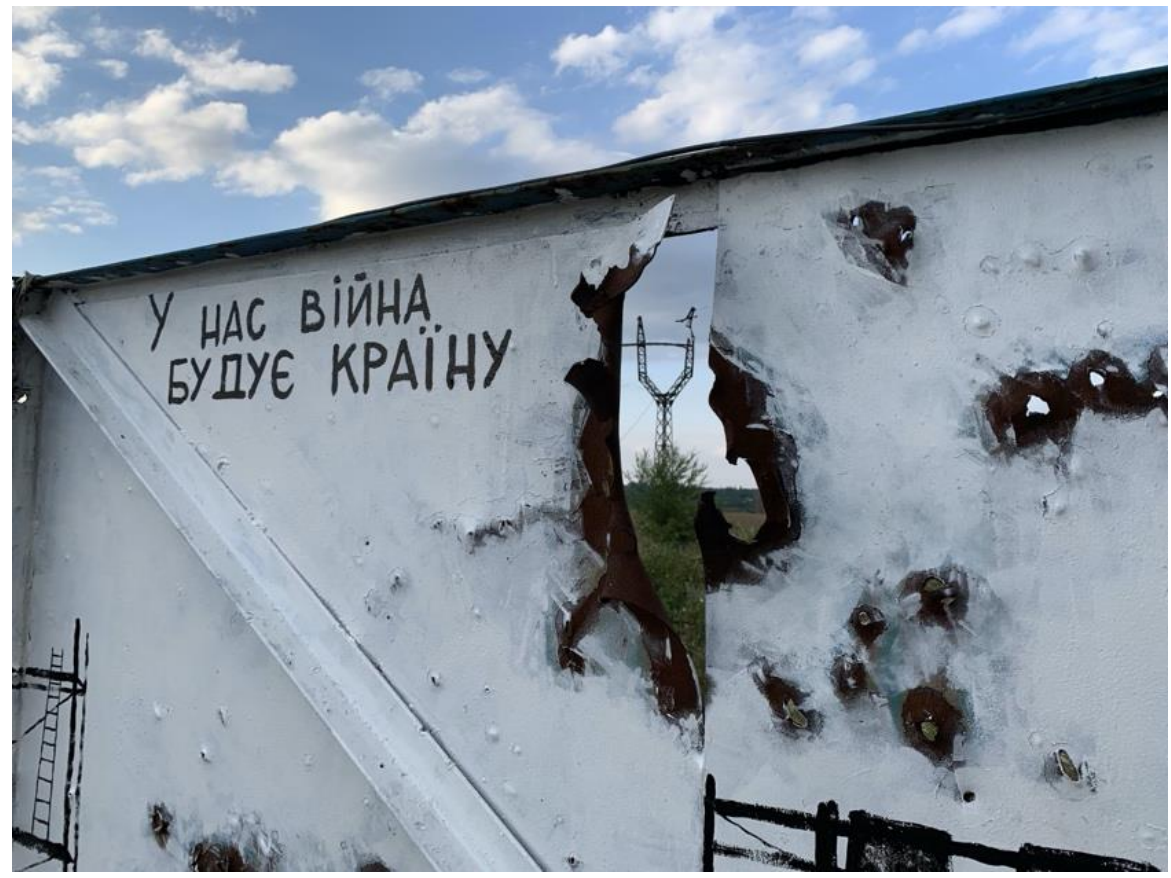

Recently, Hamlet has started to switch languages in his graffiti. As the choice of language and related identity has been an issue in Kharkiv for centuries, and continues to be a subject of debate, I asked Hamlet about his opinion on this issue, and this is what he said:

Ukrainian and Russian are both working languages for me. For the younger generation Ukrainian would be indispensable for their future careers. This attitude is indicative of the increasing value of Ukrainian on the labour market. In Kharkiv, the great portion of the population speaks a mixture of Russian and Ukrainian. But if one understands either Ukrainian or Russian, it is not a given that they understand the other. (Zyn'kovs'kyi, interview, 14 Oct. 2019)

In our conversations, we addressed his heritage language and spoke about authenticity. Hamlet noted his non-fluency in Ukrainian:

My reading skills in Ukrainian are much better than my spoken language. My Ukrainian is not learned through formal instruction, but rather acquired through contacts with Ukrainian native speakers, in oral communication with street artists from Uzhhorod during our work together on joint 
projects. I am not recovering forgotten linguistic knowledge but have acquired Ukrainian as a new language with no traces of the Soviet language and its orthographic reforms. (Zyn'kovs'kyi, interview, 3 Jan. 2019)

This was an important point to make in the context of Kharkiv's bilingual society. Thus, second-language use is a significant aspect of Hamlet's everyday life, as is a process of reclamation and ownership of the Ukrainian language as his medium.

From a sociolinguistic perspective, the current linguistic situation in Kharkiv is a unique opportunity to attest to the emergence of new patterns and to observe the perception and production of bilingual constructions in real time multilingual conversations with abundant crossing, codeswitching, and other practices of non-monolingual speech. I asked if anything is lost when he has switched to a language that is not his mother tongue and was not the one he was used to in his own family. Here is his answer: "Definitely not. I think, it is disgraceful not to speak Ukrainian in Ukraine" (Zyn'kovs'kyi, interview, 3 Jan. 2019). Unexpectedly, the language discussion with Hamlet has illuminated questions of the socio-cultural and ethnolinguistic composition of Kharkiv's population and its change over several centuries.

\section{KHARKIV LINGUISTIC DIVERSITY}

Kharkiv's linguistic diversity has historically ebbed and flowed as a result of migration into the area and political governance changes in the city. It is expected to change further with the recent displacement of people (hundreds of thousands of people) emigrating from the Donetsk and Luhansk regions. ${ }^{36}$ The linguistic diversity of Kharkiv is increasing again, providing context for a multilingualism rather than the historic bilingualism that the area has known over the Soviet years. For years, however, the most important aspect of city activists' work has been their willingness to acknowledge and assess the complexities of the forces of multiculturalism on one side and extreme nationalism on the other. Cultural observer Tat'iana Leonova, for whom multiculturalism and language autonomy is a question of both national and personal significance, elaborates on the problems young artists face:

\footnotetext{
36 The city of Donetsk is in the current war zone in Ukraine. The people I mention here are called "internally displaced persons" (they call themselves "refugees") who have fled their homes in eastern Ukraine to escape fighting between government forces and Russia-supported rebels. For these predominantly Russian-speaking citizens, the Ukrainian language holds a specific position as the national language and is a symbol of the independent Ukrainian state.
} 
This energy of the new generation is still visible and in a state of constant flux. While living and working in Kharkiv with Kharkivites, I could not help but notice how the site of multi-ethnic or international co-existence and solidarity has shifted to the level of an individual. I know that in Soviet times it was considered dangerous to express too much individuality; there was a risk of being misunderstood by society, and in an authoritarian, totalitarian society individuality could draw unwelcome attention from the authorities. It was safest to blend into the gray crowd. Now as a public art and an expression of the experiences and ideas of people who live in the buildings on those streets, graffiti is an immediate response to events and creates solidarity, even though it may be imagined solidarity that is seen as an illustration of the changes ongoing in Ukrainian society.

\section{CONCLUDING REMARKS}

My definition of linguistic landscape emphasizes the importance of identity markers of various communities imprinted in the public space, and in signage coloured with national, and even ethnic, implications. Such considerations reflect an interdisciplinary awareness, enable the examination of connections between the national past and the present, and involve questions of language motives, uses, and ideologies, especially if some particular usages have become the commonly accepted norms. Embracing the advancement of this paradigm shift as the most important task of linguistic landscape in the field of interdisciplinary studies, I offer to make connections between the linguistic landscape and the visual semiotics of the city. The discussion in this article has emphasized the need to examine the intersection of public art, sociolinguistic diversity, code-switching and mixing, and belonging and identity in Kharkiv's urban semiotics, situating these within contemporary debates on coming to terms with the past and present of Ukraine. In interviews and informal conversations with Kharkivites, it becomes obvious that debates about language policy, which politicians have often used along with controversial policies on historical commemoration, are a wedge issue, where thinkers align either with linguistic purists or against them. The majority of the older generation speaks Russian as their first language and is indifferent and reluctant to speak Ukrainian. Meanwhile, the younger generation learns Ukrainian at school. Not only have they a better command of Ukrainian than their parents, they seem able to manipulate their linguistic codes for a wide variety of stylistic purposes and situational demands. According to Pinkham, "A portion of the Ukrainian population-largely the nationalist-minded intelligentsia-is vehemently opposed to the use of Russian in public life, seeing it as a direct continuation of centuries of Russian oppression." Although I can see divisions within this monolithic strain, it can be said that 
there is a further division over the validity of "the debates about language policy that very likely provides fodder for Russian and separatist propaganda that aims to convince Russian-speakers that they are under attack from the Ukrainian authorities" (Pinkham). Thus, Kharkiv's identity construction was carried out in different historical eras and it has the impression of different cultures.

It is clear that the Maidan protests of 2013-14 unleashed a new wave of de-Communization, and throughout recent years, Kharkiv spent a lot of time and effort articulating its vision of Ukrainian sovereignty. The study of toponyms, reflecting the fact that they emerge over time, demonstrates a societal-albeit often contested-construct. Kharkiv's precarious, open, and culturally heterogeneous urban landscape is an arena for the proactive actions of those who are genuinely interested in the continuous relationship between the city's past and present, and the past speaks to us in the present. My analysis highlights the rift between the city dwellers' growing understanding of the city's history and the imperfect present as it is reflected in the urban vernacular. Ultimately, I demonstrate that the transformation of the linguistic urban landscape of Kharkiv is a project in progress.

It is my hope that the increase in use and prestige of the Ukrainian language contributes to the restoration of Kharkiv's roots and origin (or to the restoration of the city as a cultural capital of Ukraine). Similarly, I have argued that the study of everyday language practices offers a useful tool to document the narrative of synchronic and diachronic linguistic linkages and discrepancies in recreating/revealing Kharkiv's submerged Ukrainian history. 


\section{Works Cited}

Apuleev, Ivan. "Tros na sheiu: natsionalisty snesli biust Zhukova v Khar'kove." Gazeta.ru, 2019. https://www.gazeta.ru/politics/2019/06/02 a 12390115.shtml Accessed 10 Nov. 2019.

Barnes, Trevor J., and James S. Duncan. Writing Worlds. Discourse, Text and Metaphor in the Representation of Landscape. Routledge, 1992.

Bennett, Brian P. "Abecedarian Ideologies: The Old Orthography in the New Russia." Micro and Macro Connections, Seventeenth Sociolinguistics Symposium, 3-5 April 2008, Amsterdam. Conference paper. http://www.meertens.knaw.nl/ss17/contributions/index.php?pag=paper. Accessed 12 Dec. 2018.

Ben-Rafael, Eliezer, et al. "Linguistic Landscape As a Symbolic Construction of the Public Space: The Case of Israel." Linguistic Landscape: A New Approach to Multilingualism, Multilingual Matters, 2006, pp. 7-30.

---. "The Symbolic Construction of Public Space: The Case of Israel." International Journal of Multilingualism, vol. 3, no. 1, 2006, pp. 7-28.

Bertelsen, Olga. "Crossing Ethnic Barriers Enforced by the KGB: Kharkiv Writers' Lives in the 1960s-70s." East/West: Journal of Ukrainian Studies, vol. 7, no. 1, pp. 7-54.

---. "The House of Writers in Ukraine, the 1930s: Conceived, Lived, Perceived." The Carl Beck Papers in Russian and East European Studies, no. 2302, 2013. https://carlbeckpapers.pitt.edu/ojs/index.php/cbp/article/view/170. Accessed 10 Nov. 2019.

Bilaniuk, Laada. "Cultural Politics on Ukrainian Television: Language Choice and Code-Switching on 'Khoroshou'." Canadian-American Slavic Studies, vol. 44, nos. 1-2, 2010, pp. 179-94.

Boissoneault, Lorraine. "The WWII Massacres at Drobitsky Yar Were the Result of Years of Scapegoating Jews." Smithsonian.com, 15 Dec. 2016. https://www.smithsonianmag.com/history/wwii-massacres-drobitsky-yarwere-result-years-scapegoating-jews-180961466/. Accessed 28 Nov. 2019.

Bourdieu, Pierre. Language and Symbolic Power. Harvard UP, 1997.

Budnitskii, Oleg. "Rossiiskie evrei mezhdu krasnymi i belymi (1917-1920).” Mirovoi krizis 1914-1920 godov i sud'ba vostochnoevropeiskogo evreistva, edited by $0 . \mathrm{V}$. Budnitskii et al., ROSSPEN, 2005.

Certeau, Michel de. The Practice of Everyday Life. California UP, 1984.

Cohn, Norman Rufus Colin. Warrant for Genocide: The Myth of the Jewish World Conspiracy and the Protocols of the Elders of Zion. Serif, 2006.

Crane, R. From Kamchatka to Georgia: The Blue Blouse Movement and Early Soviet Spatial Practice. 2013. University of Pittsburgh, PhD dissertation.

Cresswell, Tim. In Place / Out of Place: Geography, Ideology, and Transgression. Minnesota UP, 1996.

$\mathrm{Du}$ Plessis, Theodorus. "'City on the Cove'. Language Management and Transformation of a Non-Representative Linguistic Landscape." Linguistic Landscape in the City, Multilingual Matters, 2010, pp. 74-95. 
Duncan, James S. The City as Text: The Politics of Landscape Interpretation in the Kandyan Kingdom. Cambridge UP, 2004.

Flynn, James T. "V. N. Karazin, the Gentry, and Kharkov University." Slavic Review, vol. 28, no. 2, 1969, pp. 209-20.

Fowler, Mayhill. Beau Monde on Empire's Edge: State and Stage in Soviet Ukraine. U of Toronto P, 2017.

Gaidar, Arkadii. Skazka o Voennoi taine, o Mal'chishe-Kibal'chishe i ego tverdom slove. Khudozhnik RSFSR, 1977.

Gorter, Durk. "Further Possibilities for Linguistic Landscape Research." Linguistic Landscape. A New Approach to Multilingualism, edited by Durk Gorter, Multilingual Matters, 2006, pp 81-89.

---. "Methods and Techniques for Linguistic Landscape Research: About Definitions, Core Issues and Technological Innovations." Expanding the Linguistic Landscape: Linguistic Diversity, Multimodality and the Use of Space As a Semiotic Resource, edited by Martin Pütz and Neele Mundt, Multilingual Matters, 2018, pp. 38-57. DOI: $10.21832 / 9781788922166-005$

Gospodini, A. "Urban Morphology and Place Identity in European Cities: Built Heritage and Innovative Design." Journal of Urban Design, vol. 9, no. 2, 2004, pp. 225-48.

Heller, Monica. "Globalization, the New Economy and the Commodification of Language and Identity." Journal of Sociolinguistics, vol. 7, no. 4, 2003, pp. 473-92.

Huebner, T. "Bangkok's Linguistic Landscapes: Environmental Print, Codemixing, and Language Change." Linguistic Landscape: A New Approach to Multilingualism, Multilingual Matters, 2006, pp. 31-51.

Ivanova, Natalia. "Commotion and Controversial Petitions on Victory Day in Kharkiv." Kharkiv Observer, 11 May 2019. https://kharkivobserver.com/commotion-andcontroversial-petitions-on-victory-day-in-kharkiv/. Accessed 21 June 2019.

Korniienko, Nelli. Les' Kurbas: Repetytsiia maibutn'oho. Lybid', 2007.

Kress, Gunther, and Theo van Leeuwen. Reading Images: The Grammar of Visual Design. Routledge, 2006.

Kulyk, Volodymyr. "Identity in Transformation: Russian-Speakers in Post-Soviet Ukraine." Europe-Asia Studies, vol. 71, no. 1, 2019, pp. 156-78.

---. "National Identity in Ukraine: Impact of Euromaidan and the War." Europe-Asia Studies, vol. 68, no. 4, 2016, pp. 588-608.

Lakoff, George, and Mark Johnson. Metaphors We Live by. Chicago UP, 1980.

Landry, Rodrigue, and Richard Y. Bourhis. "Linguistic Landscape and Ethnolinguistic Vitality: An Empirical Study." Journal of Language and Social Psychology, vol. 16, no. 1, 1997, pp. 23-49.

Leonova, Tat'iana. Personal interview. 19 Dec. 2018.

Liber, George O. Soviet Nationality Policy, Urban Growth, and Identity Change in the Ukrainian SSR 1923-1934. Cambridge UP, 2002.

Luk"ianets', Halyna. Personal interview. 5 Oct. 2017.

Lynch, Andrew. "Bilingualism and Second Language Acquisition." Second and Foreign Language Education. Encyclopedia of Language and Education, 3rd ed., edited by Nelleke Van Deusen-Scholl and Stephen May, Springer, 2015, pp. 43-55.

Makaryk, Irena. Shakespeare in the Undiscovered Bourn: Les Kurbas, Ukrainian Modernism, and Early Soviet Cultural Politics. U of Toronto P, 2004. 
Makaryk, Irena and Virlana Tkacz, eds. Jubilant Experimentation: Modernism in Kyiv. U of Toronto P, 2010

Marcus Aurelius. Meditations. Penguin Classics, 2006.

Massey, Doreen. For Space. SAGE, 2005.

Paramonov, A. and V. Titar', eds. Materialy k istorii Khar'kovskogo teatra, 1780-1934. Khar'kovskii chastnyi muzei gorodskoi usad'by, 2007.

Pavlenko, Aneta. "Language Conflict in Post-Soviet Linguistic Landscapes." Journal of Slavic Linguistics, vol. 17, nos. 1-2, 2009, pp. 247-74.

Pinkham, Sophie. "Ukraine's New Leading Man." The New York Review of Books, 27 June 2019. https://www.nybooks.com/articles/2019/06/27/zelenskyukraines-new-leading-man/. Accessed 14 June 2019.

Rampton, Ben. "Language Crossing and the Problematisation of Ethnicity and Socialization." Pragmatics, vol. 5, no .4, 1995, pp. 485-513.

Savchenko, Liudmyla. Personal interview. 22 July 2017.

Shkandrij, Myroslav. "Modernism, the Avant-Garde, and Mykhailo Boichuk's Aesthetic." Journal of Ukrainian Studies, vol. 19, no. 2, 1994, pp. 43-58.

Snyder, Timothy. “Ukraine’s Easy, Misunderstood Babel.” Politico, 2 July 2015. http://www.politico.eu/article/crisis-in-ukraine-talk-shows-in-languagewar/. Accessed 22 Dec. 2018.

Sokolynska, Olena. "Street Art: Between Hooliganism and Art." Den', 7 Aug. 2013. https://day.kyiv.ua/en/article/time-out/street-art-between-hooliganism-andart. Accessed 25 Dec. 2018.

Szporluk, Roman. "Ukraine: From an Imperial Periphery to a Sovereign State." Daedalus, vol. 126, no. 3, 1997, pp. 85-119.

Van Assche, Kristof, and Petruța Teampău. "Layered Encounters: Performing Multiculturalism and the Urban Palimpsest at the 'Gateway of Europe."' The Anthropology of East Europe Review, vol. 27, no. 1, 2009, pp. 7-19.

Wilson, Andrew. The Ukrainians: Unexpected Nation. Yale UP, 2002.

Woolard, Kathryn Ann. Singular and Plural: Ideologies of Linguistic Authority in 21st Century Catalonia. Oxford UP, 2016.

Yurchak, Alexei. "Privatize Your Name: Symbolic Work in a Post-Soviet Linguistic Market." Journal of Sociolinguistics, vol. 4, no. 3, 2000, pp. 406-34.

Zaiets, D. "Contemporary Public Art in the City Space of Kharkiv." Anthropology of East Europe Review, vol. 28, no. 2, 2010, pp. 279-307.

Zyn'kovs'kyi, Hamlet. Personal interview. 3 Jan. 2019; 14 Oct. 2019. 